\title{
Genetic characterization of a phospholipase C gene from Candida albicans: presence of homologous sequences in Candida species other than Candida albicans
}

\author{
Désirée E. Bennett, ${ }^{1,2}$ Christine E. McCreary ${ }^{1}$ and David C. Coleman ${ }^{1,2}$
}

Author for correspondence: David C. Coleman. Tel: +353 16081814. Fax: +35316799294.

e-mail: dcoleman@tcd.ie

1 University of Dublin, School of Dental Science, Department of Oral Medicine and Pathology, Trinity College, Dublin 2, Republic of Ireland

2 University of Dublin, The Moyne Institute of Preventive Medicine, Department of Microbiology, Trinity College, Dublin 2, Republic of Ireland
Phospholipase C (PLC) enzymes are essential in regulating several important cellular functions in eukaryotes, including yeasts. In this study, PCR was used to identify a gene encoding PLC activity in Candida albicans, using oligonucleotide primers complementary to sequences encoding highly conserved amino acid regions within the $X$ domains of previously characterized eukaryotic phospholipase $C$ genes. The nucleotide sequence of the C. albicans gene, CAPLC1 (2997 bp), was determined from a recombinant clone containing $C$. albicans 132A genomic DNA; it encoded a polypeptide of 1099 amino acids with a predicted molecular mass of $124.6 \mathrm{kDa}$. The deduced amino acid sequence of this polypeptide (CAPLC1) exhibited many of the features common to previously characterized PLCs, including specific $X$ and $Y$ catalytic domains. The CAPLC1 protein also exhibited several unique features, including a novel stretch of 18-19 amino acid residues within the $X$ domain and an unusually long $\mathbf{N}$-terminus which did not contain a recognizable EFhand $\mathrm{Ca}^{2+}$-binding domain. An overall amino acid homology of more than $\mathbf{2 7 \%}$ with PLCs previously characterized from Saccharomyces cerevisiae and Schizosaccharomyces pombe suggested that the CAPLC1 protein is a $\delta$-form of phosphoinositide-specific PLC (PI-PLC). PLC activity was detected in cell-free extracts of both yeast and hyphal forms of $C$. albicans 132A following $7 \mathrm{~h}$ and $24 \mathrm{~h}$ growth using the PLC-specific substrate p-nitrophenylphosphorylcholine (p-NPPC). In addition, CAPLC1 mRNA was detected by reverse transcriptase PCR in both yeast and hyphal forms of $C$. albicans $132 \mathrm{~A}$ at the same time intervals. Expression of CAPLC1 activity was also detected in extracts of Escherichia coli DH5 $\alpha$ harbouring plasmids which contained portions of the CAPLC1 gene lacking sequences encoding part of the $\mathbf{N}$-terminus. Southern hybridization and PCR analyses revealed that all C. albicans and Candida dubliniensis isolates examined possessed sequences homologous to CAPLC1. Sequences related to CAPLC1 were detected in some but not all isolates of Candida tropicalis, Candida glabrata and Candida parapsilosis tested, but not in the isolates of Candida krusei, Candida kefyr, Candida guillermondii and Candida lusitaniae examined. This paper reports the first description of the cloning and sequencing of a PLC gene from a pathogenic yeast species.

Keywords: Candida albicans, phosphoinositide-specific phospholipase C, CAPLC1, X domain 


\section{INTRODUCTION}

The incidence of opportunistic infections caused by species of the genus Candida has increased dramatically over the last two decades, especially in immunocompromised patients. These include individuals infected with the human immunodeficiency virus (HIV), patients with AIDS and those undergoing chemotherapy or immunosuppressive therapy. In HIV-infected patients candidal infections are largely confined to the oral cavity and the oesophagus, whereas systemic candidosis is more common in patients with neutropaenia (Coleman et al., 1997). Candida albicans is the predominant Candida species responsible for candidosis, although the incidence of infection caused by other species of Candida has increased (Sullivan et al., 1996).

Phospholipases play important roles in regulating a variety of cellular functions in mammalian cells and in lower eukaryotes, including yeasts and slime moulds. Five kinds of phospholipase activity have been described for C. albicans, including phospholipase A (Costa et al., 1968; Pugh \& Cawson, 1975, 1977; Price \& Cawson, 1977; Barrett-Bee et al., 1985); phospholipase B (Banno et al., 1985; Ibrahim et al., 1995, 1996); phospholipase C (PLC) (Costa et al., 1968; Pugh \& Cawson, 1977); lysophospholipase (Pugh \& Cawson, 1975, 1977; Price \& Cawson, 1977; Banno et al., 1985) and lysophospholipase-transacylase (Takahashi et al., 1991; Mirbod et al., 1995; Ibrahim et al., 1995). Phosphoinositide-specific phospholipase C enzymes (PI-PLCs) play a pivotal role in receptor-linked signalling at the plasma membrane of eukaryotic cells. Hydrolysis of inositol phospholipids, particularly phosphatidylinositol-4,5-bisphosphate (PIP ${ }_{2}$ ) by PI-PLCs results in the formation of secondary messenger molecules, $s n$-1,2-diacylglycerol (DAG) and inositol 1,4,5triphosphate $\left(\mathrm{IP}_{3}\right)$, which are important in the regulation of many cellular functions (Berridge, 1993). $\mathrm{IP}_{3}$ causes the releases of $\mathrm{Ca}^{2+}$ ions from internal reserves and DAG activates protein kinase $\mathrm{C}(\mathrm{PKC})$. Calcium mobilization and PKC activation are essential for many cellular activities, including secretion, cell growth and proliferation (Nishizuka, 1992; Mitchell, 1992). PI-PLCs have been categorized into three subfamilies, $\beta,-\gamma$ and $\delta$, with two to four isoforms in each. These enzyme subfamilies each contain two well-conserved amino acid regions, designated the $\mathrm{X}$ and $\mathrm{Y}$ domains, which are essential for enzyme activity (Ellis et al., 1993; Yagisawa et al., 1994). Although the overall similarity between subfamilies is low, enzymes from each of the three subfamilies can be distinguished by their primary amino acid structure and molecular size (Rhee et al., 1989). The $\delta$ isoenzymes are the smallest and simplest PI-PLCs as they contain only sequences common to all PI-PLC subfamilies and are common to all eukaryotes, from yeasts and moulds to plants and mammals. In the yeasts Saccharomyces cerevisiae and Schizosaccharomyces pombe $\delta$-type PI-PLCs are essential for growth and they are thought to be involved in relaying different nutritional and stress-related signals (Yoko-o et al., 1993; Fankhauser et al., 1995).
To date there have been no published reports describing the genetic characterization of determinants encoding PI-PLC enzymes from any Candida species. Because PIPLCs have a central function in plasma membrane receptor-linked signalling in eukaryotic cells, including yeasts and slime moulds, it is highly likely that these enzymes perform a similar function in $C$. albicans and other Candida species. The purpose of the present study was to clone and characterize a PI-PLC genetic determinant from $C$. albicans and to investigate whether similar determinants are present in a number of other Candida species. Here we report the molecular cloning and characterization of a PI-PLC genetic determinant (CAPLC1) from C. albicans and demonstrate expression of the gene in both the yeast and hyphal forms of the organism. The deduced amino acid sequence encoded by CAPLC1 exhibits organizational features common to a wide variety of PI-PLC proteins from a diverse range of eukaryotic species but also shows unique features. We also report the presence of sequences homologous to CAPLC in several Candida species other than C. albicans, including Candida dubliniensis, Candida glabrata, Candida parapsilosis and Candida tropicalis.

\section{METHODS}

Candida strains, clinical isolates and culture media. The reference Candida strains used in this study were C. albicans 132A (Gallagher et al., 1992); C. dubliniensis CD48-I and CD46 (Moran et al., 1997); C. lusitaniae NCPF 3156; and C. krusei NCPF 3321 ; the last two strains were obtained from the National Collection of Pathogenic Fungi (UK). The oral isolates used in the study included $15 \mathrm{C}$. albicans, $10 \mathrm{C}$. dubliniensis (Moran et al., 1997), 11 C. glabrata, five C. tropicalis, two C. parapsilosis and one isolate each of C. kefyr and C. guillermondii, each from separate AIDS patients with oral candidosis. Twelve C. albicans oral carriage isolates from HIV-negative normal healthy individuals were also included. The yeasts were routinely grown on Potato Dextrose agar (PDA, Oxoid) at pH 5.6 for $48 \mathrm{~h}$ at $37^{\circ} \mathrm{C}$. For liquid culture, Candida isolates and strains were routinely grown in Yeast Peptone Dextrose broth [YPD; $\left(1^{-1}\right) 10$ g yeast extract (Oxoid), $20 \mathrm{~g}$ peptone (Difco), $20 \mathrm{~g}$ glucose, $\mathrm{pH} 5 \cdot 5$ ] at $37^{\circ} \mathrm{C}$ in an orbital incubator (Gallenkamp) set at 180 r.p.m. The identity of each isolate was confirmed by their substrate assimilation patterns using the API ID 32C yeast identification system (bioMérieux), according to the manufacturer's instructions. The assimilation profiles of each isolate were examined on at least three separate occasions using different batches of ID $32 \mathrm{C}$ kits. Germ tube and chlamydospore tests were carried out on each isolate using the methods described by Sullivan $e t$ al. (1995). The identity of C. dubliniensis isolates was confirmed as described previously (Sullivan et al., 1995, 1996; Moran et al., 1997).

Bacterial strains and culture media. Escherichia coli DH5 $\alpha$ (Sambrook et al., 1989) was used as the host strain for plasmid pBluescript II $\mathrm{KS}(-)$ (Stratagene) and its recombinant derivatives and was maintained on LB agar (Sambrook et al., 1989) containing $100 \mu \mathrm{g}$ ampicillin $\mathrm{ml}^{-1}$ (LA medium). Plasmid DNA was transformed into competent $\mathrm{CaCl}_{2}$-treated $\mathrm{DH} 5 \alpha$ cells using the procedure described by Sambrook et al. (1989). Following transformation, cells were plated immediately on to LA medium containing $100 \mu \mathrm{g}$ X-Gal (Boehringer Mannheim) $\mathrm{ml}^{-1}$ and $1 \mathrm{mM}$ IPTG (Boehringer Mannheim) and trans- 
formants were selected using blue-white selection as described by Sambrook et al. (1989). For liquid culture, strains harbouring plasmids were routinely grown in LB broth (Sambrook et al., 1989) containing $100 \mu \mathrm{g}$ ampicillin $\mathrm{ml}^{-1}$ at $37^{\circ} \mathrm{C}$ in an orbital incubator (Gallenkamp) set at 180 r.p.m. Derivatives of $\mathrm{DH} 5 \alpha$ harbouring recombinant plasmids pDB008, $\mathrm{pDB} 009, \mathrm{pDB} 010, \mathrm{pDB} 016$ or $\mathrm{pDB} 017$ were grown in LB broth both with and without X-Gal $\left(100 \mu \mathrm{g} \mathrm{ml}^{-1}\right)$ and IPTG $(1 \mathrm{mM})$ for use in PLC expression studies and were routinely maintained on LA agar medium. Large- and smallscale $E$. coli plasmid DNA preparations were performed as described by Sambrook et al. (1989).

The procedures used for the preparation of lambda phage stocks and the isolation of lambda phage DNA from E. coli phage lysates were as described by Sambrook et al (1989). E. coli strain LE 392 (Sambrook et al., 1989) and its P2 phage lysogenic derivative, P2 393 (Sambrook et al., 1989), were used for propagating the bacteriophage lambda cloning vector EMBL3 (Promega) and its recombinant derivatives, respectively, on LB medium supplemented with $10 \mathrm{mM} \mathrm{MgSO}_{4}$ and $0.2 \%(\mathrm{w} / \mathrm{v})$ maltose as described by Sambrook et al. (1989). For liquid culture, organisms for phage infection were routinely grown in LB medium containing $10 \mathrm{mM} \mathrm{MgSO}_{4}$ and $0.2 \%(\mathrm{w} / \mathrm{v})$ maltose at $37^{\circ} \mathrm{C}$ in an orbital incubator (Gallenkamp) set at 180 r.p.m.

Chemicals, enzymes and radioisotopes. Analytical-grade or molecular-biology-grade chemicals were purchased from Sigma, BDH or Boehringer Mannheim. $\left[\alpha^{32}\right.$ P]dATP $(3000 \mathrm{Ci}$ $\mathrm{mmol}^{-1} ; 110 \mathrm{TBq} \mathrm{mmol}{ }^{-1}$ ) was purchased from Amersham. Restriction endonucleases, T4 DNA ligase (3000 Weiss units $\mathrm{ml}^{-1}$ ), Klenow DNA polymerase (5000 units $\left.\mathrm{ml}^{-1}\right)$, RNase-free DNase (10000 units $\left.\mathrm{ml}^{-1}\right)$ and Taq DNA polymerase (5000 units $\mathrm{ml}^{-1}$ ) were purchased from Promega or from Boehringer Mannheim and were used according to the manufacturer's instructions.

DNA hybridization. Probe DNA used in Southern hybridization experiments was labelled with $\left[\alpha^{32} \mathrm{P}\right] \mathrm{dATP}$ $\left(3000 \mathrm{Ci} \mathrm{mmol}^{-1} ; 110 \mathrm{TBq} \mathrm{mmol}^{-1}\right.$ ) by the use of a random hexanucleotide primer labelling kit (Prime-a-Gene, Promega), which was used according to the manufacturer's instructions. Membrane filters containing bound DNA were processed under conditions of high stringency $\left(>60^{\circ} \mathrm{C}\right)$ as described by Sambrook et al. (1989), using a rotary hybridization oven (Hybaid).

Isolation of genomic DNA for hybridization analysis and PCR. Total cellular DNA from Candida isolates was prepared according to the method described by Sullivan et al. (1995). Restriction-endonuclease-generated fragments were separated by electrophoresis through $0.8 \%(\mathrm{w} / \mathrm{v})$ horizontal agarose gels using 0.5 $\times$ TBE buffer (Sambrook et al., 1989) as the electrophoresis buffer for $15 \mathrm{~h}$ at $2 \mathrm{~V} \mathrm{~cm}^{-1}$. Following electrophoresis, DNA fragments were transferred to MagnaGraph nylon membrane filters (MSI) by the method of Southern (1975). Hybridization experiments were repeated on at least two occasions with separate preparations of genomic DNA.

PCR. Two degenerate PCR primers, termed CAPHO5 and CAPHO6, respectively (Table 1), were designed which were complementary to DNA sequences encoding two highly conserved amino acid regions within the $\mathrm{X}$ domain of 22 previously characterized PLC proteins from seven separate eukaryotic species (Table 2). One of these degenerate primers (CAPHO5) consisted of a 26 bp forward primer complementary to a sequence encoding the conserved amino acid sequence SSHNTYL, which also included the 6 bp recognition sequence for the restriction endonuclease EcoRI at the $5^{\prime}$ end. The reverse primer (CAPHO6) consisted of a 43 bp oligonucleotide which was complementary to a sequence encoding the amino acid sequence GCRC(I/V)E(L/I)D(C/V)W(D/N)G and which also included the $6 \mathrm{bp}$ recognition sequence for the restriction endonuclease $X b a \mathrm{I}$ at the $5^{\prime}$ end. PCR amplification was performed in a $100 \mu \mathrm{l}$ reaction mixture containing $60 \mathrm{pmol}$ each of the forward and reverse primers, $10 \mathrm{mM}$ deoxynucleoside triphosphates, $2.5 \mathrm{mM} \mathrm{MgCl}{ }_{2}, 10 \mathrm{mM}$ Tris $(\mathrm{pH}$ 9.0 at $25^{\circ} \mathrm{C}$ ), $50 \mathrm{mM} \mathrm{KCl}, 0.1 \%$ (v/v) Triton X-100, $2.5 \mathrm{U}$ Taq DNA polymerase and $500 \mathrm{ng}$ C. albicans $132 \mathrm{~A}$ total cellular DNA. PCR reactions were performed in a DNA thermal cycler (Perkin Elmer Cetus) with 35 cycles of 1 min at $94^{\circ} \mathrm{C}, 2 \mathrm{~min}$ at $37^{\circ} \mathrm{C}$ and $3 \mathrm{~min}$ at $72^{\circ} \mathrm{C}$. To complete the last cycle of amplification, the mixture was incubated for $10 \mathrm{~min}$ at $72{ }^{\circ} \mathrm{C}$. Following amplification, $10 \mu \mathrm{l}$ aliquots of each PCR mixture was subjected to agarose gel electrophoresis using $0.5 \times$ TBE buffer through either $2 \%$ (w/v) low-EEO agarose (Sigma) or $2 \%(\mathrm{w} / \mathrm{v})$ Seakem agarose (FMC) gels containing $0.5 \mu \mathrm{g}$ ethidium bromide $\mathrm{ml}^{-1}$ and the amplimers viewed on a UV transilluminator (UVP). Experiments were repeated on at least two occasions with separate preparations of target genomic DNA.

Cloning of PCR products. Individual PCR products were separately purified from Seakem agarose gels following electrophoresis by excising the appropriate portion of agarose into a sterile $1.5 \mathrm{ml}$ Eppendorf microcentrifuge tube containing $500 \mu \mathrm{l}$ sterile distilled water followed by boiling for $5 \mathrm{~min}$. Three microlitres of this extract were then used as a DNA template for further PCR experiments as before except that annealing temperatures of $42^{\circ} \mathrm{C}$ and $45^{\circ} \mathrm{C}$ were used instead of $37^{\circ} \mathrm{C}$. These higher annealing temperatures ensured that only single PCR products were subsequently amplified. These were purified immediately following amplification by extraction with an equal volume of phenol/chloroform $(1: 1$, $\mathrm{v} / \mathrm{v}$ ) followed by precipitation with $0.3 \mathrm{M}$ sodium acetate and 2 vols ice-cold $100 \%$ (v/v) ethanol. Aliquots of each purified PCR product were then co-digested with EcoRI and $X b a \mathrm{I}$ and cloned into EcoRI- and XbaI-cleaved vector plasmid pBluescript.

DNA sequencing. DNA sequencing was performed by the dideoxy chain-termination method of Sanger $e$ t al. (1977) as described by Sambrook et al. (1989) using an automated Applied Biosystems 370A DNA sequencer and fluorescentdye-labelled primers (FLASH kit, Genpak). Searches of the EMBL and GenBank databases for nucleotide and amino acid sequence similarities were performed using the BLAST family of computer programs (Altschul et al., 1990). Protein sequence analysis was performed using the programmes within the GCG Wisconsin package (Genetics Computer Group, 1994).

Purification of $C$. albicans 132A cellular DNA for library construction. High-molecular-mass total cellular DNA from C. albicans strain $132 \mathrm{~A}$ was isolated using a modification of the method described by Sullivan et al. (1995) as follows. After zymolyase treatment, the resulting spheroplasts were harvested and washed once in TE buffer and resuspended in $1 \mathrm{ml}$ of $25 \%$ (w/v) sucrose in $50 \mathrm{mM} \mathrm{Tris} / \mathrm{HCl}, 1 \mathrm{mM}$ EDTA at $\mathrm{pH} 8 \cdot 0$. This solution was incubated at $37^{\circ} \mathrm{C}$ for $10 \mathrm{~min}$ and then transferred to ice followed by the addition of $2 \mathrm{mg}$ proteinase $\mathrm{K}$ and then $400 \mu \mathrm{l} 0.5 \mathrm{M}$ EDTA, $\mathrm{pH} 8 \cdot 0$, and $250 \mu \mathrm{l}$ $10 \%(\mathrm{w} / \mathrm{v})$ sodium $\mathrm{N}$-lauroyl sarcosinate. After thorough mixing, the spheroplast suspension was incubated on ice for $90 \mathrm{~min}$, after which it was transferred to a shaking waterbath at $50^{\circ} \mathrm{C}$ and incubated for $16 \mathrm{~h}$. Following incubation, to each lysate was added $8 \mathrm{ml}$ of a CsCl solution consisting of $69.9 \mathrm{~g}$ $\mathrm{CsCl}, 55 \cdot 2 \mathrm{ml} \mathrm{TE}$ buffer and $50 \mu \mathrm{g}$ PMSF $\mathrm{ml}^{-1}$. This mixture was then transferred into $10 \mathrm{ml}$ Quickseal ultra-clear cen- 
trifuge tubes (Beckman) and centrifuged for $40 \mathrm{~h}$ at $160000 \mathrm{~g}$ at $10^{\circ} \mathrm{C}$ in a Beckman $70.1 \mathrm{Ti}$ fixed-angle rotor using an L8$60 \mathrm{M}$ ultracentrifuge (Beckman). After centrifugation, DNA was collected from the tubes by side-puncture with an 18 gauge syringe needle (Microlance 2, Becton-Dickson). Caesium chloride was removed from the DNA by dialysis overnight $(16 \mathrm{~h})$ against 5 litres $1 \times \mathrm{TE}$ buffer at $4^{\circ} \mathrm{C}$ using dialysis tubing (Sigma). DNA was recovered by ethanol precipitation, dried, resuspended in TE buffer at $\mathrm{pH} 8.0$ and stored in aliquots at $-20^{\circ} \mathrm{C}$.

Construction of a C. albicans 132A genomic DNA library. A lambda EMBL3 library was constructed by ligating Sau3Agenerated partial digest products of $C$. albicans $132 \mathrm{~A}$ chromosomal DNA greater than $10 \mathrm{~kb}$ in size with BamHI-generated pre-prepared lambda bacteriophage replacement vector EMBL3 arms (Promega) followed by packaging in vitro into pre-prepared phage heads and tails (Promega) according to the manufacturer's instructions. Lambda EMBL3 has been shown previously to have a cloning capacity of $9-23 \mathrm{~kb}$ (Frischauf et al., 1983). Following in vitro packaging, recombinant phage particles were propagated on the E. coli P2 lysogenic strain P2 392 as described by Sambrook et al. (1989). A recombinant lambda library containing $7 \cdot 5 \times 10^{4}$ p.f.u. was obtained. The probability of a given sequence not being contained in the library was calculated as $2 \cdot 4 \times 10^{-17}$, using the equation of Kurtz et al. (1990), estimating the C. albicans genome as approximately $29.4 \mathrm{Mb}$ in size and estimating the mean insert size in the library to be approximately $15 \mathrm{~kb}$.

Recombinant phages were propagated on E. coli LE392 to yield $\sim 600-700$ p.f.u. per plate for $10 \times 90 \mathrm{~mm}$ Petri plates and were transferred from the plaques onto nitrocellulose membrane filters (Schleicher and Schuell) by overlaying the plaques with the filters, which were then screened by plaque hybridization (Sambrook et al., 1989) using the $\alpha{ }^{32}$ P-labelled cloned amplimer contained in pDB001. The genomic DNA of a recombinant EMBL3 phage, termed P7, which hybridized strongly with the probe was purified as described by Sambrook et al. (1989). The cloned DNA insert of P7 (Fig. 1) was mapped with restriction endonucleases and specific fragments were subcloned into pBluescript by conventional methods (Sambrook et al., 1989).

Pulsed-field gel electrophoresis (PFGE). Yeast chromosomes were prepared in agarose plugs as described by Vazquez et al. (1991) and were separated in $1.3 \%(\mathrm{w} / \mathrm{v})$ agarose gels using the CHEF-Mapper PFGE system (Bio-Rad). The electrophoresis buffer used was $0.5 \times \mathrm{TBE}$ and was maintained at $14{ }^{\circ} \mathrm{C}$ using buffer recycling through a Bio-Rad minichiller (model 1000). Gels were run for $22 \mathrm{~h}$ with an initial switch time of $60 \mathrm{~s}$ and a final switch time of $280 \mathrm{~s}$, with a ramping factor of $-2 \cdot 379$. Following electrophoresis, gels were stained with $0.5 \mu \mathrm{g}$ ethidium bromide $\mathrm{ml}^{-1}$ for $20 \mathrm{~min}$, destained for between 20 and $90 \mathrm{~min}$ in distilled water and viewed on a UV transilluminator.

Preparation of cell-free protein extracts from Candida strains and isolates. Cell-free protein extracts from Candida strains and isolates were prepared by mechanical lysis using glass beads. Briefly, separate $50 \mathrm{ml}$ volumes of YPD broth were inoculated with $1 \times 10^{5}$ cells $\mathrm{ml}^{-1}$ of each strain or isolate, and placed in a shaking orbital incubator, set at 200 r.p.m., for $20 \mathrm{~h}$ at $37^{\circ} \mathrm{C}$, after which time the cultures had a final cell density of approximately $1 \times 10^{8}$ cells $\mathrm{ml}^{-1}$. The inocula were prepared by diluting cells from $4 \mathrm{~h}$ YPD broth cultures in sterile saline to yield the required cell density. Cells were harvested by centrifugation at $5900 \mathrm{~g}$ (Sepatech Megafuge 1.0 , Heraeus) for $10 \mathrm{~min}$ and washed once in sterile saline. Yeast cell pellets were resuspended in $1 \mathrm{ml} p$-nitrophenylphosphoryl- choline ( $p$-NPPC) assay buffer $(60 \%, w / v$, sorbitol buffered with $0.25 \mathrm{M}$ Tris/ $\mathrm{HCl}$, pH 7.2; Kurioka \& Matsuda, 1976). This suspension was lysed using $1 \mathrm{~g}$ glass beads $(0.45-0.5 \mathrm{~mm}$ diameter; Sigma) by vortexing in a Maximix Plus (Thermolyne) vortex using a cycle of $5 \times 1 \mathrm{~min}$ with $1 \mathrm{~min}$ intermittent cooling on ice. The glass beads were then separated by centrifugation for $5 \mathrm{~min}$ at $1500 \mathrm{~g}$ and the resulting supernatant was further centrifuged at $10600 \mathrm{~g}$ in an Eppendorf centrifuge (model 5417C) for $5 \mathrm{~min}$ to yield a cellfree protein extract. The concentration of total protein $(\mathrm{mg}$ $\mathrm{ml}^{-1}$ ) in each extract was determined using a kit based on the Bradford protein assay system (Bio-Rad) used according to the manufacturer's instructions.

Preparation of cell-free protein extracts from $E$. coli strains harbouring pBluescript and derivatives. The method used to prepare cell free homogenates from $E$. coli $\mathrm{DH} 5 \alpha$ derivatives harbouring plasmids was essentially that described above for Candida strains and isolates, except that L broth (supplemented with $100 \mu \mathrm{g}$ ampicillin $\mathrm{ml}^{-1}$ to maintain plasmids) was used as growth medium and a lysis cycle of $3 \times 1 \mathrm{~min}$ with $1 \mathrm{~min}$ with intermittent cooling on ice was used. Cell-free supernatants were generated and protein concentrations determined as described above.

Spectrophotometric assay of phospholipase C activity. Candida strains and isolates and E. coli $\mathrm{DH} 5 \alpha$ derivatives harbouring plasmids pBluescript, pDB008, pDB009, pDB010, pDB016 or pDB017 were assayed for PLC activity using the phospholipase-C-specific substrate $p$-NPPC by a modification of the method described by Kurioka \& Matsuda (1976). Briefly, $90 \mu$ freshly prepared protein extract from each isolate was assayed in 96-well round-bottomed microtitre plates (Corning) by the addition of $10 \mu \mathrm{l} 200 \mathrm{mM}$ p-NPPC $(20 \mathrm{mM}$ final concn) in $60 \%(\mathrm{w} / \mathrm{v})$ sorbitol buffered with $0.25 \mathrm{M}$ Tris $/ \mathrm{HCl}(\mathrm{pH} 7 \cdot 2)$, and incubated at $37^{\circ} \mathrm{C}$ for $20 \mathrm{~h}$. The rate of $p$-NPPC hydrolysis by PLC was determined by measuring free $p$-nitrophenol at $405 \mathrm{~nm}$ using an ELISA plate reader (Spectra I; SLT-Labinstruments). For each series of test experiments, standard concentrations of PLC (type IX, from Clostridium perfringens; 6.6 units of activity per mg of solid; Sigma) with known units of activity in $\mu \mathrm{g} \mathrm{ml}^{-1}$ were assayed in a reaction mixture containing $20 \mathrm{mM}$ p-NPPC, $60 \%(\mathrm{w} / \mathrm{v})$ sorbitol buffered with $0.25 \mathrm{M}$ Tris $/ \mathrm{HCl}(\mathrm{pH} 7 \cdot 2)$ at $37^{\circ} \mathrm{C}$ for $20 \mathrm{~h}$ to generate a standard curve of PLC activity for each experiment. The activity units of PLC (based on concentration) for each isolate tested were calculated from the slope of the standard curve generated in the same experiment. The activity of PLC was expressed as units per mg total protein in cell-free extract for each isolate tested. One unit of activity was defined as the amount of enzyme that will liberate $1.0 \mu \mathrm{mol} p$-nitrophenol from $\mathrm{p}$-NPPC $\min ^{-1}$ at $37^{\circ} \mathrm{C}, \mathrm{pH} 7 \cdot 2$.

RNA isolation, reverse transcription and PCR. Total cellular RNA was isolated from $7 \mathrm{~h}$ and $24 \mathrm{~h} \mathrm{C}$. albicans $132 \mathrm{~A}$ blastospore cultures grown in YPD broth medium at $37^{\circ} \mathrm{C}$ and from hyphal cultures grown in Yeast Nitrogen-base Proline medium at $37^{\circ} \mathrm{C}$ (NYP; Gallagher et al., 1992) using the procedure of Hube et al. (1994). Total cellular RNA was also isolated from $7 \mathrm{~h}$ YPD broth cultures of the oral isolates C. dubliniensis CD48-I, C. tropicalis 709A, C. glabrata 803A and C. parapsilosis $701 \mathrm{~A}$ using the same procedure. Total RNA was reverse transcribed in a reaction volume of $20 \mu \mathrm{l}$ containing $1 \mathrm{mM}$ each of dATP, dGTP, dCTP and dTTP, $0.5 \mu \mathrm{g}$ ( $\mu \mathrm{g}$ RNA) $)^{-1}$ of oligo(dT) ${ }_{15}$ as primer, a buffer consisting of $10 \mathrm{mM}$ Tris/ $\mathrm{HCl}, \mathrm{pH} 8.8,50 \mathrm{mM} \mathrm{KCl}, 5 \mathrm{mM} \mathrm{MgCl}_{2}$ and $0 \cdot 1 \%(\mathrm{v} / \mathrm{v})$ Triton X-100 and 15 units of avian myeloblastosis virus reverse transcriptase, in the presence of rRNasin ribonuclease inhibitor (RT-PCR kit, Promega). The reaction 
Table 1. PCR primers used in this study

\begin{tabular}{|c|c|c|c|}
\hline $\begin{array}{l}\text { Primer } \\
\text { name }\end{array}$ & Sequence ${ }^{*}$ & $\begin{array}{l}\text { Length } \\
\text { (bp) }\end{array}$ & $\begin{array}{c}\mathrm{RE} \\
\text { site† }\end{array}$ \\
\hline CAPHO5 & 5'-TCGGAATTCTSYCAYAAYACKTAYCT- $3^{\prime}$ & 26 & EcoRI \\
\hline CAPHO6 & 5'-GCTCTAGACCRTYYCARMWRTCRAYYTCKAYACAGCGRCAKCC- $3^{\prime}$ & 43 & $X b a \mathrm{I}$ \\
\hline XDOM F & 5'-ACTGGTCGACAAGTTGCTGG-3' & 20 & SalI \\
\hline XDOM R & 5'-AGCAAAGCTTATTGGTTTAG-3' & 20 & HindIII \\
\hline PLCS2 & 5'-TCGGAATTCTCGAAAAGTAAAGACGG-3' & 26 & EcoRI \\
\hline PLCE & 5'-GAACTAGTTGTTATCTTCCCCATG-3' & 24 & SpeI \\
\hline ACT F & 5'-CGGAATTCCGCTTCTTCTCAATCTTCTGCC- $3^{\prime}$ & 30 & EcoRI \\
\hline ACT R & 5'-CGGAATTCCGAATGGATGGACCAGATTCGTCG-3' & 32 & EcoRI \\
\hline
\end{tabular}

${ }^{*} \mathrm{R}=\mathrm{A}$ or $\mathrm{G} ; \mathrm{Y}=\mathrm{C}$ or $\mathrm{T} ; \mathrm{K}=\mathrm{G}$ or $\mathrm{T} ; \mathrm{M}=\mathrm{A}$ or $\mathrm{C} ; \mathrm{S}=\mathrm{G}$ or $\mathrm{C} ; \mathrm{W}=\mathrm{A}$ or $\mathrm{T}$.

† Restriction endonuclease recognition sequence included within the primer sequence (underlined).

was carried out at $42{ }^{\circ} \mathrm{C}$ for $60 \mathrm{~min}$. Approximately equal amounts of $(50 \mathrm{ng}) \mathrm{RNase}$-free DNase-treated total cellular RNA was added for each sample as determined spectrophotometrically $\left(A_{260}\right)$ and visually following electrophoresis in $1.5 \%(\mathrm{w} / \mathrm{v})$ agarose gels containing $6 \%(\mathrm{v} / \mathrm{v})$ formaldehyde as described by Hube et al. (1994). PCR reactions were performed in a Perkin Elmer Cetus DNA thermal cycler. The reactions were essentially those described for DNA PCR (see above) except that reaction mixtures contained $20 \mathrm{pmol}$ of each primer and $8 \mu \mathrm{l}$ of each cDNA sample was added as template. The primers used were XDOM F and XDOM R (Table 1). PCR conditions were 35 cycles at $94^{\circ} \mathrm{C}$ for $1 \mathrm{~min}$, $55^{\circ} \mathrm{C}$ for $1 \mathrm{~min}$ and $72^{\circ} \mathrm{C}$ for $1 \mathrm{~min}$, followed by a further $10 \mathrm{~min}$ at $72{ }^{\circ} \mathrm{C}$. Reaction products were analysed by electrophoresis through $2 \%(\mathrm{w} / \mathrm{v})$ agarose gels. In addition to a PCR negative control to which no template was added, other negative controls included reactions in which DNase-treated RNA that had not been reverse transcribed was used as a template for each RNA preparation tested. These controls were used to ensure that RNA preparations used for cDNA synthesis were not contaminated with cellular DNA. Genomic DNA from $C$. albicans $132 \mathrm{~A}$ was used as a positive PCR control in each PCR experiment. Two primers, ACT F and ACT R (Table 1), were designed to amplify a 440 bp product from within the $C$. albicans actin gene (Losberger $\&$ Ernst, 1989) and these were used with each cDNA sample tested to act as a positive control for cDNA synthesis and subsequent PCR.

Northern analysis. For Northern blots, total RNA was extracted and electrophoresed in $1.5 \%(\mathrm{w} / \mathrm{v})$ agarose gels containing $6 \%(\mathrm{v} / \mathrm{v})$ formaldehyde as described by Hube et al. (1994). Following electrophoresis, RNA was transferred to MagnaGraph nylon membrane filters (MSI) by capillary action and the RNA was bound to the membranes by baking at $80^{\circ} \mathrm{C}$ for $30 \mathrm{~min}$ and UV cross-linking as described by Hube et al. (1994). Probe DNA was labelled as described above for Southern analysis. Membrane filters containing bound RNA were hybridized at $42^{\circ} \mathrm{C}$ by the method of Hube et al. (1994) using a rotary hybridization oven (Hybaid). Detection of the translation elongation factor 3 gene (TEF3) mRNA transcript (Colthurst et al., 1992), which is constitutively expressed in C. albicans yeast and hyphal forms (Swoboda et al., 1994), was used as a positive control in all Northern experiments using an $0.7 \mathrm{~kb}$ internal fragment of the TEF3 gene as described by Hube et al. (1994) as a probe. Membranes were stripped of bound probe for subsequent rehybridization by immersion in boiling water for $10 \mathrm{~min}$.
Cloning the entire CAPLC1 gene. To obtain a clone containing the entire CAPLC1 gene, PCR primers were designed to amplify the entire open reading frame of $3297 \mathrm{bp}$ and the transcriptional control sequences (an additional $474 \mathrm{bp}$ ). PCR amplifications were performed in a Perkin Elmer Cetus DNA thermal cycler in a final reaction volume of $100 \mu \mathrm{l}$ which contained $300 \mathrm{nM}$ of each primer, $200 \mu \mathrm{M}$ deoxynucleotide triphosphates, $2.25 \mathrm{mM} \mathrm{MgCl}_{2}, 50 \mathrm{mM}$ Tris/ $\mathrm{HCl}(\mathrm{pH} 9.2$ at $\left.25^{\circ} \mathrm{C}\right), 14 \mathrm{mM}\left(\mathrm{NH}_{4}\right)_{2} \mathrm{SO}_{4}, 2 \%$ (v/v) dimethyl sulfoxide, $0 \cdot 1 \%(\mathrm{v} / \mathrm{v})$ Tween 20, 2.6 U Taq and Pwo DNA polymerase enzyme mix (Expand High Fidelity PCR system, Boehringer Mannheim) and $500 \mathrm{ng}$ C. albicans $132 \mathrm{~A}$ total cellular DNA. The primers used were PLCS2 and PLCE (Table 1). After an initial denaturation step of $94^{\circ} \mathrm{C}$ for $2 \mathrm{~min}$, PCR conditions were 10 cycles of $94^{\circ} \mathrm{C}$ for $10 \mathrm{~s}, 45^{\circ} \mathrm{C}$ for $30 \mathrm{~s}$ and $68^{\circ} \mathrm{C}$ for 4 min followed by 15 cycles of $94^{\circ} \mathrm{C}$ for $10 \mathrm{~s}, 45^{\circ} \mathrm{C}$ for $30 \mathrm{~s}$ and $68^{\circ} \mathrm{C}$ for $4 \mathrm{~min}$ with an extension of $20 \mathrm{~s}$ for each cycle at the elongation temperature, followed by a prolonged elongation step of $7 \mathrm{~min}$ at $68^{\circ} \mathrm{C}$. Reaction products were analysed by electrophoresis through $0.8 \%(\mathrm{v} / \mathrm{v})$ agarose gels. PCR products were purified immediately after amplification by extraction with an equal volume of phenol/chloroform $(1: 1, \mathrm{v} / \mathrm{v})$ followed by precipitation with $0.3 \mathrm{M}$ sodium acetate and 2 vols ice-cold $100 \%(v / v)$ ethanol. Aliquots of each purified PCR product were then co-digested with EcoRI and SpeI and cloned into EcoRI- and SpeI-cleaved vector plasmid pBluescript.

\section{RESULTS AND DISCUSSION}

\section{Production of phospholipase $C$ by $C$. albicans 132A}

PI-PLC activity in cell-free extracts of C. albicans 132A was determined spectrophotometrically using the PIPLC-specific chromogenic substrate $p$-NPPC. Extracts of C. albicans $132 \mathrm{~A}$ from cultures grown in the yeast phase in YPD broth for $20 \mathrm{~h}$ yielded a PLC activity of $15 \cdot 1 \pm 1.8 \times 10^{-2}$ units (mg protein) ${ }^{-1}$ (mean $\pm \mathrm{sD}, n=$ 7). In contrast, extracts from cultures grown in the hyphal phase in NYP broth for $20 \mathrm{~h}$ yielded a PLC activity of $39.0 \pm 1.7 \times 10^{-2}$ units (mg protein $)^{-1}(2 \cdot 6$-fold increased activity). Similar results were obtained in separate experiments. The significance of the higher PLC activity in the hyphal phase compared to the yeast phase is presently unknown but could reflect relative rates of membrane synthesis in the two phases. These 
Table 2. Predicted amino acid consensus regions within the $X$ domain encoded by previously characterized phospholipase $\mathrm{C}$ genes used for oligonucleotide primer design

\begin{tabular}{|c|c|c|c|c|}
\hline \multirow[t]{2}{*}{ Species } & \multirow[t]{2}{*}{ Gene name } & \multirow{2}{*}{$\begin{array}{c}\text { GenBank } \\
\text { accession } \\
\text { no. }\end{array}$} & \multicolumn{2}{|c|}{$\begin{array}{c}\text { Consensus amino acid sequences } \\
\text { used for primer design }\end{array}$} \\
\hline & & & $\begin{array}{l}\text { Forward } \\
\text { primer }\end{array}$ & $\begin{array}{l}\text { Reverse } \\
\text { primer }\end{array}$ \\
\hline \multirow[t]{2}{*}{ Saccharomyces cerevisiae } & SCPLC & L13036 & SSHNTYL & GCRCVEIDIWDG \\
\hline & SCPLC1 & D12738 & SSHNTYL & GCRCVEIDIWDG \\
\hline Dictyostelium discoideum & DDPHOSPHC & M95783 & SSHNTYL & GCKCVELDVWDG \\
\hline \multirow[t]{3}{*}{ Drosophila melanogaster } & $D M P L C 21 A$ & M60452 & SSHNTYL & GCRCVELDFWNG \\
\hline & $D M P L C 21 B$ & M60453 & SSHNTYL & GCRCVELDFWNG \\
\hline & $D M N O R P A$ & J03138 & SSHNTYL & GCRCVELDCWNG \\
\hline Xenopus laevis & XLPHSLPC & L20816 & SSHNTYL & GCRCIELDCWKG \\
\hline \multirow[t]{4}{*}{ Rattus norvegicus } & RSPLC3A & M20637 & SSHNTYL & GCRCLELDCWDG \\
\hline & RNBETA4AA & L15556 & SSHNTYL & GCRCIELDCWDG \\
\hline & RNPLPIV & J05155 & SSHNTYL & GCRCIELDCWDG \\
\hline & RRPPLCA & J03806 & SSHNTYL & GCRCIELDCWDG \\
\hline \multirow[t]{6}{*}{ Bos taurus } & BTPHOSA & L13935 & SSHNTYL & GCRCVELDCWDG \\
\hline & BTPHOSB & L13936 & SSHNTYL & GCRCVELDCWDG \\
\hline & BTPHOSC & L13937 & SSHNTYL & GCRCVELDCWDG \\
\hline & BTPHOSD & L13938 & SSHNTYL & GCRCVELDCWDG \\
\hline & BTPIPLC & J03137 & SSHNTYL & GCRCVELDCWKG \\
\hline & $B T P L C 3 A$ & M20638 & SSHNTYL & GCRCLELDCWDG \\
\hline \multirow[t]{5}{*}{ Homo sapiens } & HSPLC & X14034 & SSHNTYL & GCRCIELDCWDG \\
\hline & HSPLCA & M34667 & SSHNTYL & GCRCIELDCWDG \\
\hline & HSPLPC & Z16411 & SSHNTYL & GCRCVELDVWKG \\
\hline & HSPLC01 & M37238 & SSHNTYL & GCRCIELDCWDG \\
\hline & HSPLCB2A & M95678 & SSHNTYL & GCRCVELDCWKG \\
\hline
\end{tabular}

results demonstrated unequivocally that C. albicans 132A expressed PLC activity.

\section{Identification of a C. albicans phospholipase C gene}

In an attempt to identify a C. albicans PLC determinant using PCR, a pair of degenerate oligonucleotide primers, termed CAPHO5 and CAPHO6 respectively, were designed (Table 1), which were complementary to sequences encoding two non-contiguous conserved amino acid regions from within the $\mathrm{X}$ domains of 22 previously characterized phospholipase $C(P L C)$ genes from seven separate eukaryotic species (Table 2). The predicted sizes of amplimers which would be obtained with target DNA from these genes (Table 2) using these primers would be approximately $130 \mathrm{bp}$ in each case. Ten PCR products were obtained with target genomic DNA from C. albicans $132 \mathrm{~A}$, ranging in size from 100 to $800 \mathrm{bp}$, four of which were $>350 \mathrm{bp}$. Because the predicted size of amplimers obtainable with the PLC genes listed in Table 2 was much smaller, the four larger C. albicans $132 \mathrm{~A}$ amplimers were not studied further. Each of the six smaller amplimers was purified and


sequences were determined. The sequence of one amplimer of $130 \mathrm{bp}$ cloned in the recombinant plasmid pDB001 was found to be highly homologous $(65 \%$ sequence identity) to the corresponding nucleotide sequence encoding the $\mathrm{X}$ domain of the PLC gene of the fission yeast Schiz. pombe (67\% predicted amino acid identity, $91 \%$ similarity; Fankhauser et al., 1995). Sixtynine basepairs of the $130 \mathrm{bp}$ amplimer cloned in pDB001 consisted of primer sequences used for amplification; the deduced amino acid sequence of the remaining $61 \mathrm{bp}$ was $68 \%$ identical $(89 \%$ similar $)$ to residues of the $\mathrm{X}$ domain encoded by the Schiz. pombe PLC gene. These data indicated that pDB001 was likely to encode part of a C. albicans 132A PLC determinant and it was subsequently used as a probe to screen a C. albicans 132A genomic DNA library. None of the remaining five cloned amplimers showed any significant sequence homology to other PLC genes in the GenBank database. The sequence of the amplimer cloned in pDB001 is indicated in Fig. 2.

\section{Isolation and physical mapping of a C. albicans phospholipase C gene}

Plaques from a C. albicans 132A genomic DNA library constructed in the lambda vector EMBL3 were hybridized with the $\alpha^{3}{ }^{32} \mathrm{P}$-labelled insert from pDB001 and hybridization signals were obtained which corresponded to seven individual plaques from a total of approximately 7000 screened. The recombinant phage from the plaque yielding the strongest signal was chosen for further study and the phage termed P7. Phage P7 

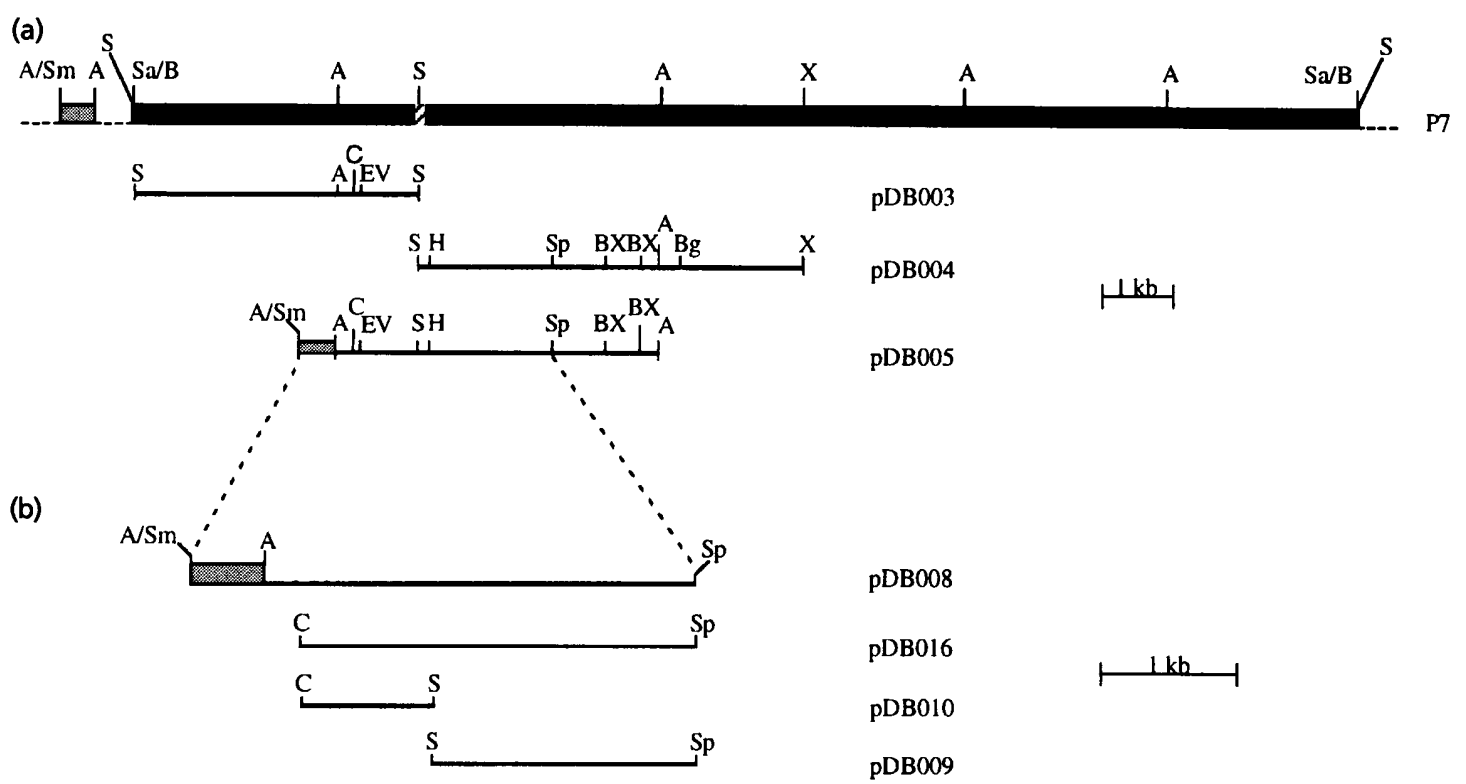

(c)

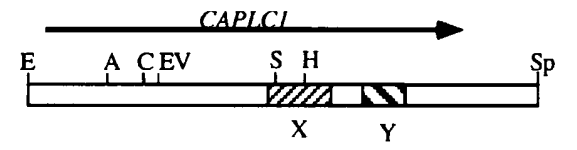

pDB017

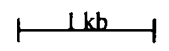

\begin{abstract}
Fig. 1. (a) Restriction map of the $C$. albicans $132 \mathrm{~A}$ genomic DNA cloned in recombinant phage $P 7$, which is represented by the black rectangular box. The dashed lines at both ends of the rectangular box represent phage EMBL3 sequences. The shaded box to the left represents the location of a $0.5 \mathrm{~kb}$ Aval fragment of EMBL3 DNA which was subcloned along with the $4.5 \mathrm{~kb}$ Aval fragment of P7 insert DNA in recombinant plasmid pDB005. The small hatched area within the black rectangular box represents the location of sequences corresponding to the insert DNA of pDB001. The thin black lines in the lower part of the figure represent specific fragments of P7 insert DNA that were subcloned in vector plasmid pBluescript. The names of the recombinant plasmids are shown on the right. (b) The thin black lines represent specific fragments of pDB005 that were subcloned from P7 insert DNA in pBluescript. The names of the plasmids are shown on the right. (c) Restriction map of recombinant plasmid pDB017 encoding the entire C. albicans CAPLC1 gene, which is represented by a white rectangular box, on a $3.7 \mathrm{~kb}$ ECoRI-Spel fragment amplified by PCR from C. albicans $132 \mathrm{~A}$ genomic DNA and cloned in pBluescript. The arrowed line at the top represents the position and shows the direction of transcription of the ORF encoding the CAPLC1 gene. The hatched boxes represent sequences encoding the $X$ and $Y$ domains of the predicted translation product encoded by CAPLC1. Restriction endonuclease cleavage sites are abbreviated as follows: S, Sall; A, Aval; C, Clal; E, EcoRI; EV, EcoRV; H, HindIII; Sa, Sau3A; Sp, Spel; B, BamHI; BX, BstXI; Bg, Bg/ll; X, Xbal.
\end{abstract}

harboured a cloned DNA insert of approximately $18 \mathrm{~kb}$ which contained a single internal SalI restriction site (Fig. 1). The cloned amplimer in pDB001 also contained a single internal SalI site, which indicated that the region of shared DNA homology with the DNA of P7 spanned the internal SalI site (Fig. 1). Furthermore, pDB001 insert DNA hybridized with each of the $4.0 \mathrm{~kb}$ Sall, the $4.5 \mathrm{~kb}$ SalI-XbaI and the $4.5 \mathrm{~kb}$ AvaI fragments of P7 following subcloning in pBluescript to yield plasmids pDB003, pDB004 and pDB005, respectively (Fig. 1). This evidence, together with the homology shared between the cloned amplimer DNA in pDB001 and the Schiz. pombe PLC determinant, suggested that the region of P7 DNA spanning the internal SalI site very probably encoded a PLC determinant from C. albicans 132A. To investigate this possibility further, the $3.0 \mathrm{~kb}$ Aval-SpeI fragment of pDB005 was subcloned into plasmid pBluescript to yield $\mathrm{pDB} 008$. The entire nucleotide sequence of the $3.0 \mathrm{~kb}$ AvaI-SpeI insert of pDB008 was determined; part of it is shown in Fig. 2.
While subcloning fragments of the insert DNA from phage P7 into pBluescript, recombinant plasmids harbouring only the $4.5 \mathrm{~kb}$ Aval fragment which hybridized with pDB001 were never recovered. In two separate experiments, AvaI fragments of $\mathrm{P} 7$ were ligated into AvaI-digested pBluescript; following transformation into E. coli DH5 $\alpha 169$ transformants harbouring recombinant plasmids were screened, 19 of which were found to contain the $4.5 \mathrm{~kb} A v a \mathrm{I}$ fragment in conjunction with an additional $0.5 \mathrm{~kb} \mathrm{Aval}$ fragment as in pDB005 (Fig. 1). None of the transformants harboured the $4.5 \mathrm{~kb}$ AvaI fragment alone. Attempts to recover pDB005 derivatives which had lost the $0.5 \mathrm{~kb}$ AvaI fragment following digestion with Aval followed by ligation and transformation into $\mathrm{DH} 5 \alpha$-were unsuccessful, despite repeated attempts. Furthermore, recombinant derivatives harbouring the $3.0 \mathrm{~kb}$ AvaI-SpeI fragment of pDB005 subcloned in pBluescript as in pDB008 also contained this $0.5 \mathrm{~kb}$ Aval fragment (Fig. 1). Nucleotide sequence analysis of this $0.5 \mathrm{~kb}$ AvaI 


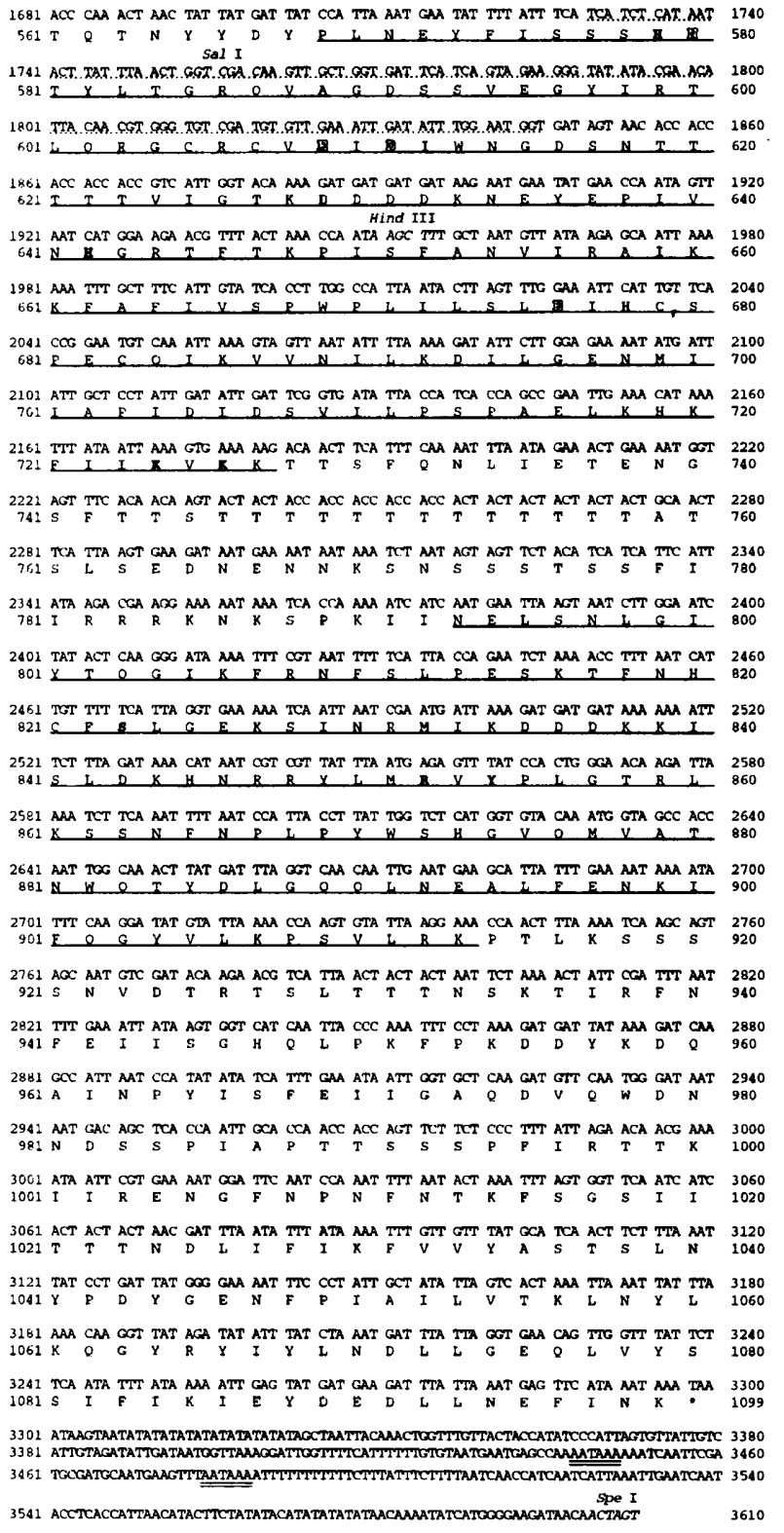

Fig. 2. Nucleotide sequence and deduced amino acid sequences of the region of the CAPLC1 gene encoding the $X$ and $Y$ domains. Nucleotide sequences are numbered in the $5^{\prime}$ to $3^{\prime}$ direction from the first base $(+1)$ of the ATG translation start codon. Amino acid sequences are numbered from the initial methionine. Amino acid residues of the CAPLC1 $X$ domain (residues 569-727) and $Y$ domain (residues 793-913) are underlined. Conserved residues thought to be important for binding $\mathrm{IP}_{3}$ and $\mathrm{Ca}^{2+}$ in the $\mathrm{X}$ and $\mathrm{Y}$ domains (active site) in previously characterized PLC genes are highlighted. Nucleotide sequences corresponding to the amplimer cloned in pDB001 are indicated by dotted underlining (nucleotide co-ordinates 1728-1845). Two potential polyadenylation signal sequences (starting at nucleotides 3445 and 3480 ) are doubly underlined. The positions of unique restriction endonuclease cleavage sites are shown.

fragment showed that it originated from the lambda EMBL3 left arm, corresponding to EMBL3 nucleotides 19397-19951 (Frischauf et al., 1983). Further analysis of the sequence revealed that the two Aval sites of the $0.5 \mathrm{~kb}$ Aval fragment had different recognition sequences. One of these also functioned as a SmaI cleavage site (recognition sequence CCCGGG; see Fig. 1) and was compatible with an AvaI site in pBluescript. The other Aval site (recognition sequence ATGCCC) was compatible with the Aval site of the $3.0 \mathrm{~kb}$ AvaI-SpeI fragment of P7 cloned in pDB008 (Fig. 1) and was incompatible with both pBluescript AvaI sites (recognition sequences CCCGGG and CTCGAG). Because the Aval sites of the $4.5 \mathrm{~kb}$ Aval fragment and of the $3.0 \mathrm{~kb}$ AvaI-SpeI fragment cloned in plasmids pDB005 and pDB008, respectively, were incompatible with both AvaI sites in pBluescript, the $0.5 \mathrm{~kb} A v a \mathrm{I}$ fragment of EMBL3 DNA, also present in both of these plasmids, acted as a linker to facilitate cloning of the larger fragments, in each case. However, repeated attempts to blunt-end clone the $3.0 \mathrm{~kb}$ AvaI-SpeI fragment of pDB008 after filling-in of the AvaI site with the Klenow fragment of DNA polymerase failed, but clones containing the $0.5 \mathrm{~kb} A v a \mathrm{I}$ fragment of EMBL3 were obtained.

\section{Sequence analysis of the $C$. albicans 132A PLC gene}

Computer analysis of the entire nucleotide sequence of $3.0 \mathrm{~kb}$ Aval-SpeI fragment from pDB008 revealed an incomplete ORF. To locate the transcription/ translation start site of this ORF the nucleotide sequence of the region of DNA $5^{\prime}$ to the AvaI site was determined by primer walking along the cloned DNA insert in pDB003 until an ATG/methionine start codon which was preceded by a stop codon and transcription initiation control sequences was observed. In total, approximately $4 \mathrm{~kb}$ of DNA sequence was obtained, which contained one large ORF of $3297 \mathrm{bp}$, termed CAPLC1. This sequence has been deposited in the EMBL nucleotide sequence database (accession number Y13975). Sequences identical to the fungal consensus transcriptional control sequences CAAG (potential ribosome-binding site), CT-block and TATAA are located at positions -28 and $-31,-81$ to -110 , and -114 to -118 , respectively (Brown \& Lithgow, 1987) [numbering the sequences in the $5^{\prime}$ to $3^{\prime}$ direction from the first base $(+1)$ of the translation start codon]. Furthermore, consensus sequences for two potential polyadenylation signals (AATAAA) are located starting at nucleotide 3445 and 3480,148 and $189 \mathrm{bp}$, respectively, after the translation termination codon (Fig. 2).

The CAPLC1 ORF has the capacity to encode a protein of 1099 amino acids with 16 predicted glycosylation sites, all asparagine residues, with a predicted molecular mass of $124.6 \mathrm{kDa}$ and a $\mathrm{pI}$ of $8 \cdot 16$, which is larger in size compared to $\delta$-form PI-PLCs of other yeasts, including that of Sacch. cerevisiae (869 amino acids; Yoko-o et al., 1993) and Schiz.pombe (899 amino acids; Fankhauser $e t$ al., 1995). Comparison of the deduced amino acid sequence of the CAPLC1 protein with the predicted amino acid sequences of $\delta$-form PLCs encoded by the eight most similar PLC genes representative of different 


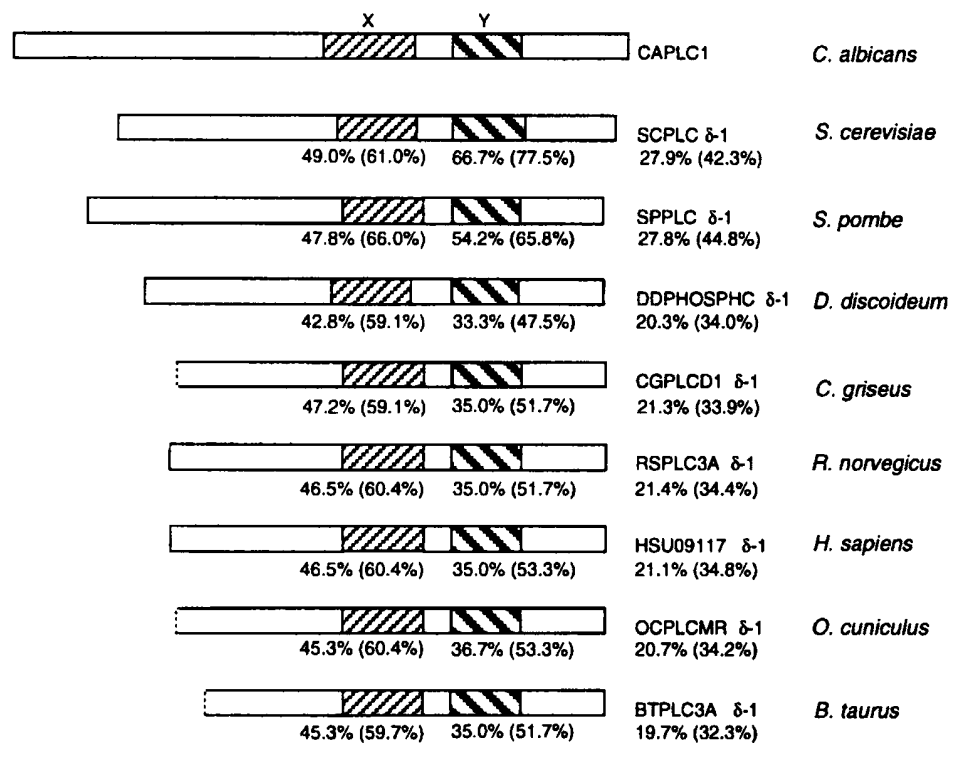

$\stackrel{100 \text { a.a }}{\longmapsto}$
Fig. 3. Comparison of the primary structure of the predicted translation product of the CAPLC1 gene and the corresponding translation products of the eight most similar PLC genes representative of different eukaryotic species encoding phospholipase $C$ $\delta-1$ isoforms in the GenBank database. The percentage overall amino acid identity of CAPLC1 to each of the other phospholipases is shown under each phospholipase name and the percentage similarity is shown in parentheses. The $X$ and $Y$ domains of each phospholipase are shown as hatched boxes. The percentage amino acid identity between the CAPLC1 $X$ and $Y$ domains, respectively, and the corresponding regions of the other phospholipases are indicated beneath each phospholipase and the percentage similarity is shown in parentheses. The phospholipases compared are as follows: CAPLC1, C. albicans (this study); SCPLC, Sacch. cerevisiae; SPPLC, Schiz. pombe; DDPHOSPHC, Dictyostelium discoideum; CGPLCD1, Cricetulus griseus; RSPLC3A, Rattus norvegicus; HSU09117, Homo sapiens; OCPLCMR, Oryctolagus cuniculus; BTPLC3A, Bos taurus. The dashed line at the N-termini of CGPLCD1, OCPLCMR and BTPLC $3 A$ indicates that the complete $\mathrm{N}$ terminal sequence was not available from the GenBank database. eukaryotic species in the GenBank database, including Schiz. pombe (Fankhauser et al., 1995), Sacch. cerevisiae (Yoko-o et al., 1993), Dictyostelium discoideum (Drayer \& van Haastert, 1992), Bos taurus (Suh et al., 1988), Rattus norvegicus (Suh et al., 1988), Cricetulus griseus (Leonis \& Silbert, 1996), Oryctolagus cuniculus (Milting et al., 1996) and Homo sapiens (Cheng et al., 1995) shows more than $19 \%$ overall amino acid identity ( $>32 \%$ similarity) over the entire protein (Fig. 3 ). The predicted CAPLC1 protein exhibits many of the features common to other PLCs, especially with $\delta$-form isoenzymes, including amino acid regions which correspond to the $\mathrm{X}$ and $\mathrm{Y}$ domains that are important for catalytic activity in other PLCs (Rhee et al., 1989; Rhee \& Choi, 1992; Ellis et al., 1993; Yagisawa et al., 1994; Cheng et al., 1995; Essen et al., 1996). The N-terminal part of the CAPLC1 protein preceding the $\mathrm{X}$ domain shows $<20 \%$ sequence identity with the predicted amino acid sequences of the eight most similar PLC genes representative of different eukaryotic species and is significantly larger in size in each case, at 568 amino acids in length (the $\mathrm{N}$-termini of the eight most similar PLC genes representative of different eukaryotic species range from between 239 and 445 amino acids in length). Surprisingly, the N-terminal region of the CAPLC1 protein did not contain a recognizable EF-hand domain (putative $\mathrm{Ca}^{2+}$-binding site) using the Motifs program of the GCG Wisconsin software package (Genetics Computer Group, 1994). Furthermore, no sequence within the CAPLC1 protein shared any significant similarity with 45 known EF-hand proteins ( $R$. Kretsinger, personal communication). However, as three-dimensional structure is more conserved than amino acid sequence, an EF-hand domain or else other sequences which perform the same role may still be present within CAPLC1. This finding was unique to the predicted CAPLC1 protein, as DNA sequences of all previously characterized eukaryotic PLC genes, including those from yeasts and slime moulds, encoded a relatively conserved 29-residue EF-hand domain sequence (Bairoch \& Cox, 1990; Essen et al., 1996). It has long been known that mammalian PLC $\delta 1$ enzymes have an absolute requirement for $\mathrm{Ca}^{2+}$ for activity and the EFhand domain is thought to be essential for activity (Mitchell, 1992; Nishizuka, 1992; Berridge, 1993). This has been confirmed for rat brain PLC $\delta 1$, as deletion of approximately one half of the EF-hand domain completely abolished enzyme activity (Nakashima et al., 1995). The precise role of the EF-hand domain is unclear but one possibility is that it may be important in maintaining the C-terminal region in the appropriate three dimensional configuration (Essen et al., 1996).

The region of CAPLC1 corresponding to the X domain is 159 amino acids in size, which is greater than the predicted sizes for this domain of between 137 and 141 amino acids for the other eight most similar PLC genes representative of different eukaryotic species in the GenBank database. This variation in size is due to a stretch of 18-19 additional amino acids located within the CAPLC1 $\mathrm{X}$ domain which do not align with any residues within the corresponding $\mathrm{X}$ domains of all other PLCs (19 residues for yeast PLCs and 18 residues for PLCs from higher eukaryotes) in the EMBL database 
CAPLC1 569 PLNEYFISSSHNTYLTGRQVAGDSSVEGYIRTLQRGCRCVEIDIWNGDSNTTTTTVIGTKDDDDKNEYEPIVNHGRTFTK

SCPLC 384 PLNHYFIASSHNTYLLGKQIAETPSVEGYIQVLQQGCRCVEIDIWDGENG-_...-..........-. PVVCHG-FLTS

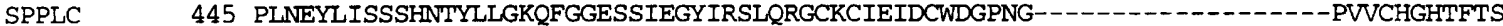



CGPLCD1S3 289 PLSHYLVSSSHNYLLEDQLTGPSSTEAYIRALCKGCRCLELDCWDGPNQE-_-_-_-_-_.--_-_-_PIIYHGYTFTS

RSPLC3A 300 PLSHYLVSSSHNTYLLEDQLTGPSSTEAYIRAICKGCRCLELDCWDGPNQE----------------PIIYHGYTFTS

HSU09117 301 PLSHYLVSSSHNTYLLEDQLAGPSSTEAYIRALCKGCRCLELDCWDGPNQE--_-_---_-_---_----PIIYHGYTFTS

OCPLCMR 289 PLSHYLVSSSHNTYLLEDQLTGPSSTEAYIRALCKGCRCLELDCWDGPSLE- - - . - . -

BTPLC3A 239 PLSHYLVSSSHNTYLLEDQLTGPSSTEAYIRALCKGCRCLELDCWDGPNQE--------------- PIIYHGYTFTS

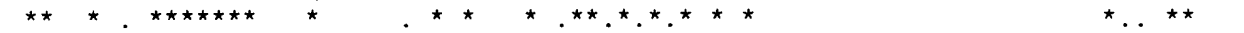

CAPLC1 649 PISFANVIRAIKKFAFIVSPWPLILSLEIHCSPECQIKVVNILKDILGENMIIAPIDIDSVILPSPAEIKKHKFIIKVKK 727

SCPLC 444 AIPLKTVIRVIKKYAFITSPYPLIISLEINCNKDNQKLASLIMREVLAEQLYFVGTRTDK--LPSPREL_KHKILLKSKK 521

SPPLC 506 MIKFNDVIDAIRKYAFVVSPYPLFISLEIHCCPDQQRQMVSYMKQAFGDTLVMKPVTANESVLPSPEDLLNKILLKVKC 585

DDPHOSPHC 386 QIKFSHVCETIKARGFETSPYPVILSLEVHCSVPQQIMMANHMKEIFG-EMLPTPLPEGTKELPTLDSLKYKILLKG-- 464

CGPLCD1S3 351 KILFYDVLRAIRDYAFKASPYPVILSLENHCSLEQQQVMARHLKAILGPMLLDQPLDGVTMSLPSPEQLKGKILLKGKK 430

RSPLC3A 362 KILFCDVLRAIRDYAFKASPYPVILSLENHCSLEQQRVMARHLRAILGPILLDQPLDGVTTSLPSPEQLKGKILLKGKK 441

HSU09117 363 KILFCDVLRAIRDYAFKASPYPVILSLENHCTLEOQRVMARHLHAILGPMLLNRPLDGVTNSLPSPEQLKGKILLKGKK 442

OCPLCMR 351 KILFCDALRAIRDYAFKVSPYPVILSLENHCSLEQQRVMARHLRTLLGPMLLDRPLDGVTSSLPSPEQLKGKILLKGKK 430

BTPLC3A 301 KILFCDVVRAIRDYAFKASPYPVILSLENHCSLEQQRVMARHLRTLLGPMLLDRPLDGVVTSLPSPEQLRGKILLKGKK 380

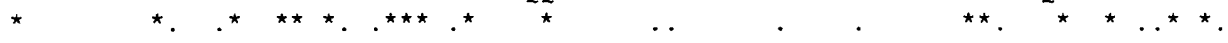

\begin{abstract}
Fig. 4. Alignment of the predicted amino acid sequence of the $X$ domain of the CAPLC1 gene and the corresponding predicted amino acid sequences of the $X$ domains of the eight most similar PLC genes representative of different eukaryotic species in the GenBank database. The $X$ domain encoded by CAPLC1 contains a novel region consisting of 18-19 amino acid residues, a corresponding region for which is absent from the $X$ domains of the other phospholipases. Amino acid sequences were aligned using the cLusTAL sequence alignment computer program (Higgins \& Sharp, 1988). The phospholipase residues aligned were as follows: CAPLC1, C. albicans (this study); SCPLC, Sacch. cerevisiae; SPPLC, Schiz. pombe; DDPHOSPHC, Dictyostelium discoideum; CGPLCD1, Cricetulus griseus; RSPLC3A, Rattus norvegicus; HSU09117, Homo sapiens; OCPLCMR, Oryctolagus cuniculus; BTPLC3A, Bos taurus. Asterisks indicate identical residues and dots represent similar residues. Dashes indicate gaps created to obtain alignment.
\end{abstract}

(Fig. 4). These residues are highly hydrophilic, have a high surface probability (Emini et al., 1985), have a high chain flexibility (Karplus \& Schulz, 1985) and have a high Jameson-Wolf antigenicity index (Wolf et al., 1987) as determined by the PeptideStructure computer program (Genetics Computer Group, 1994). However, despite these additional amino acid residues the $\mathrm{X}$ domain of CAPLC1 exhibits more than $42 \%$ amino acid identity ( $>59 \%$ similarity) to the corresponding $\mathrm{X}$ domains of the other eight PLCs indicated in Fig. 4. The CAPLC1 X domain also contains two conserved histidine residues (at positions 579 and 642) which have been shown to be essential for enzyme activity in previously characterized PLCs (Fig. 2). The X domain also contains conserved asparagine, glutamine, aspartic acid and glutamine residues at positions 580, 609, 611 and 676 , respectively, which have been shown to be essential for the binding of calcium in other PLCs (Fig. 2; Essen et al., 1996). The region of the CAPLC1 protein between the $\mathrm{X}$ and $\mathrm{Y}$ domains is 65 amino acids in length, which is within the range of 48-72 amino acids for the corresponding region of the other PLCs. This region also contains a stretch of 13 threonine residues which do not correspond with any residues within the corresponding regions of the other PLCs.

The region of CAPLC1 corresponding to the $\mathrm{Y}$ domain is 121 amino acids in size, which is similar to the predicted size for this domain of 120 amino acids for the other eight PLC genes in the EMBL database (Rhee et al., 1989; Drayer \& van Haastert, 1992). This region exhibited $>33 \%$ identity ( $>47 \%$ similarity) with the
Y domains of the eight most similar PLCs representative of different eukaryotic species in the GenBank database, and contained three residues (a serine at position 823, an arginine at position 852 and a tyrosine at position 854 ) which have been shown to be conserved in previously characterized PI-PLCs, and which are considered important in determining substrate specificity and for catalysis (Essen et al., 1996; Fig. 2). Finally, the Cterminal part of $\delta$-form PLC proteins after the Y domain can vary from 147 to 159 amino acids. The $\mathrm{C}$-terminal part of the CAPLC1 is 187 amino acids in size and is $<26 \%$ homologous ( $<43 \%$ similar) to the $\mathrm{C}$ termini of the other PLC proteins examined

\section{Phenotypic expression of CAPLC1 in E. coli}

To investigate whether expression of the CAPLC1 gene could be detected in E. coli, protein extracts from DH $5 \alpha$ containing either pDB017 or pDB008 or subclones derived from it were tested for PLC activity using the PLC-specific chromogenic substrate $p$-NPPC. A previous study has reported the expression of a trypanosomal PLC gene in E. coli (Mensa-Wilmot \& Englund, 1992). Plasmid pDB017 contained the entire CAPLC1 gene, including putative transcriptional control sequences, cloned on a $3.7 \mathrm{~kb}$ fragment amplified from C. albicans $132 \mathrm{~A}$ template DNA using the primer set PLCS2 and PLCE (Table 1). Extracts from DH5 $\alpha$ harbouring pDB017 failed to exhibit levels of PLC activity above those detected with extracts of DH5 $\alpha$ harbouring pBluescript only. Because the cloned DNA within pDB017 was obtained by PCR amplification, it is 
possible that misincorporation of single nucleotides could have occurred, leading to premature termination of transcription even though the proofreading polymerase $P w o$ was included with Taq polymerase during amplification. Similar results were obtained when five $3.7 \mathrm{~kb}$ amplimers, recovered in separate experiments with $C$. albicans $132 \mathrm{~A}$ target DNA, were cloned in pBluescript and DH5 $\alpha$ extracts tested for PLC activity. It is also possible that the CAPLC1 putative transcriptional control sequences contained in pDB017 (promoter and ribosome-binding site) do not function efficiently in E. coli.

Extracts from $\mathrm{DH} 5 \alpha$ harbouring pDB008 consistently (seven separate experiments) yielded an approximately twofold higher (mean 2.03 \pm 0.35 higher) level of activity with the $p$-NPPC substrate compared to DH5 $\alpha$ harbouring $p B l u e s c r i p t$ only. Furthermore, extracts from DH5 $\alpha$ harbouring pDB016 (Fig. 1) also consistently yielded higher levels of activity, although lower than those obtained with pDB008, compared to extracts from DH5 $\alpha$ harbouring pBluescript only or pDB010 (Fig. 1). In a typical experiment the activity in units ( $\mathrm{mg}$ protein $)^{-1}$ detected in extracts from $\mathrm{DH} 5 \alpha$-harbouring (i) $\mathrm{pDB} 017$ was $11.7 \times 10^{-2}$, (ii) $\mathrm{pDB} 008$ was $28.1 \times 10^{-2}$, (iii) pBluescript was $15.3 \times 10^{-2}$, (iv) pDB016 was $23.0 \times 10^{-2}$, (v) pDB009 was $19.8 \times 10^{-2}$ and (vi) pDB010 was $17.6 \times 10^{-2}$.-Similar results were obtained regardless of whether IPTG was present or absent from the growth medium, suggesting that the PLC activity expressed from the CAPLC1-encoding plasmids was not under control of the inducible lac promoter of pBluescript. Analysis of the CAPLC1 sequences in pDB017, pDB016, pDB010 and pDB009 revealed that the cloned fragments were not in the correct reading frame to be expressed as fusion proteins with $\beta$-galactosidase.

The above expression studies indicated that the truncated CAPLC1 gene $(82 \%)$ encoded by pDB008 was expressed in E. coli at a low level. Furthermore, recombinant plasmid pDB016, which encoded a more extensively truncated CAPLC1 gene $(72 \%$; Fig. 1$)$, but which retained sequences encoding the $\mathrm{X}$ and $\mathrm{Y}$ domains of the CAPLC1 protein, expressed residual PLC activity in $E$. coli. These results suggest that the CAPLC1 Nterminus is not essential for PLC catalytic activity. Previous studies have shown that the $\mathrm{N}$-terminal 135 amino acids of rat brain PLC $\delta 1$ and the N-terminal 60 amino acids of bovine brain PLC $\delta 1$ were not required for activity (catalysis) but were essential for substrate binding (Ellis et al., 1993; Yagisawa et al., 1994; Cifuentes et al., 1993). It is likely that the PLC activity detected in $E$. coli $\mathrm{DH} 5 \alpha$ derivatives harbouring $\mathrm{pDB} 008$ or pDB016 was due to expression of a truncated CAPLC1 protein, containing a functional catalytic domain in each case. The increased PLC activity detected in extracts of $E$. coli harbouring pDB008 compared to pDB016 could be due to translation of the truncated CAPLC1 gene in pDB008 and the $0.5 \mathrm{~kb}$ AvaI EMBL3 sequence located $5^{\prime}$ to these sequences as a fusion protein (see Fig. 1). The $0.5 \mathrm{~kb}$ AvaI fragment within pDB008 contained an internal TATA sequence and encoded an in-frame methionine putative translational start site $18 \mathrm{bp} 5^{\prime}$ to the AvaI site within CAPLC1 (Fig. 1). These results, together with similarities in the sequence homology of CAPLC1 and in the structural organization of the deduced CAPLC1 protein in comparison to other previously characterized PLC genes, provided convincing evidence that CAPLC1 encodes a functional PLC determinant.

Plasmid pDB008, encoding $82 \%$ of the CAPLC1 gene, had an adverse effect on the growth of E. coli DH5 $\alpha$, which may have been due to expression of PLC activity. In eleven separate experiments the final cell density of $20 \mathrm{~h} \mathrm{~L}$-broth cultures of DH5 $\alpha$ harbouring pDB008 was approximately half that obtained with $\mathrm{DH} 5 \alpha$ harbouring pBluescript only under the same experimental conditions. In seven separate experiments the protein concentration $\left(\mathrm{mg} \mathrm{ml}^{-1}\right)$ in cell-free extracts from $20 \mathrm{~h}$ cultures of DH5 $\alpha$ harbouring pDB008 was consistently more than twofold lower (mean 2.36 \pm 0.5 fold lower) compared to extracts from cells harbouring pBluescript only. In a typical experiment the protein concentration determined from cell extracts of $\mathrm{DH} 5 \alpha$ harbouring pDB008 was $2.13 \mathrm{mg} \mathrm{ml}{ }^{-1}$ compared to $5.02 \mathrm{mg} \mathrm{ml}^{-1}$ for DH $5 \alpha$ harbouring pBluescript only. No significant difference was observed in the corresponding cell densities or protein concentrations of cell extracts of DH5 $\alpha$ harbouring pDB017, pDB016, pDB009, pDB010, pBluescript or pBluescript derivatives containing the $0.5 \mathrm{~kb}$ Aval fragment of EMBL3 obtained following blunt-end cloning.

Extracts of E. coli $\mathrm{DH} 5 \alpha$ harbouring only pBluescript exhibited levels of PLC activity $\left[15 \pm 0.4 \times 10^{-2}\right.$ units $\left.(\text { mg protein })^{-1}\right]$ (mean $\left.\pm \mathrm{SD}, n=7\right)$ which were similar to those detected with extracts of $C$. albicans $132 \mathrm{~A}$ $\left.\left[15 \cdot 1 \pm 1.8 \times 10^{-2} \text { units (mg protein) }\right)^{-1}\right]$. The levels of PLC activity detected in the former extracts were higher than but of the same order of magnitude as the sum of PLC activities previously reported in three membrane fractions of $E$. coli strain B using a radiometric assay (Bayer \& Bayer, 1985).

\section{Expression of CAPLC1 in C. albicans}

To detect expression of the CAPLC1 gene in C. albicans and to determine whether the sequences encoding the novel stretch of 19 amino acids in the X domain of the deduced translation product were expressed, a pair of primers termed XDOM F and XDOM R, respectively (Table 1), which were complementary to sequences flanking this region were made. These primers were designed to amplify a $210 \mathrm{bp}$ amplimer encoding a $202 \mathrm{bp}$ region of CAPLC1 DNA (the remaining $8 \mathrm{bp}$ consisted of primer clamp sequences and restriction sites; Table 1) corresponding to nucleotides 1750-1959 as shown in Fig. 2. These primers yielded a single amplimer of $210 \mathrm{bp}$ following PCR amplification with target genomic DNA from C. albicans $132 \mathrm{~A}$. If the sequences encoding the novel stretch of 18-19 amino acids in the CAPLC1 $X$ domain were expressed, a product of $210 \mathrm{bp}$ would be expected when cDNA from 
(a)
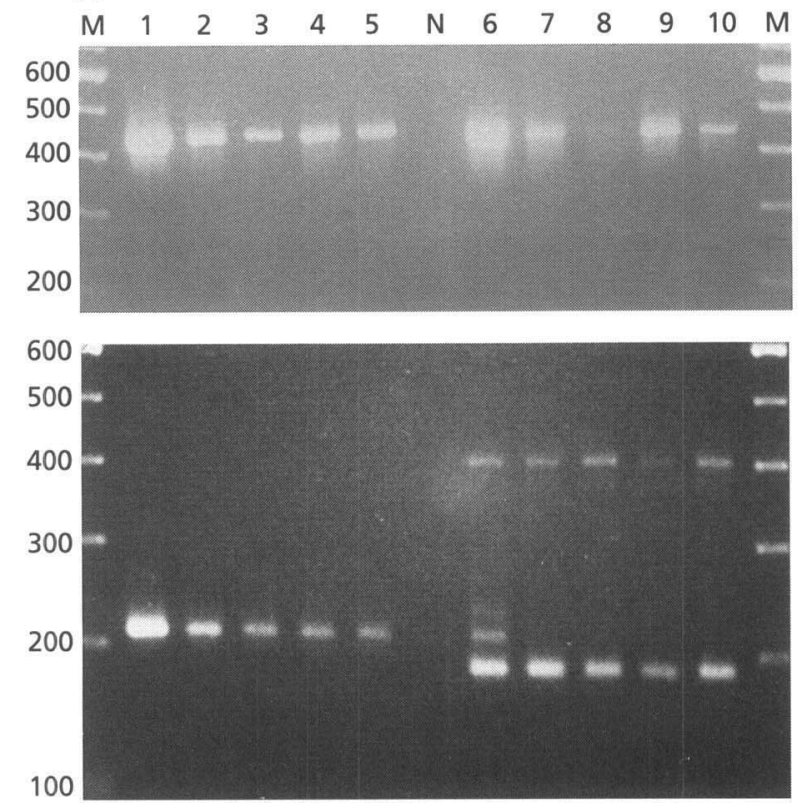

(b)
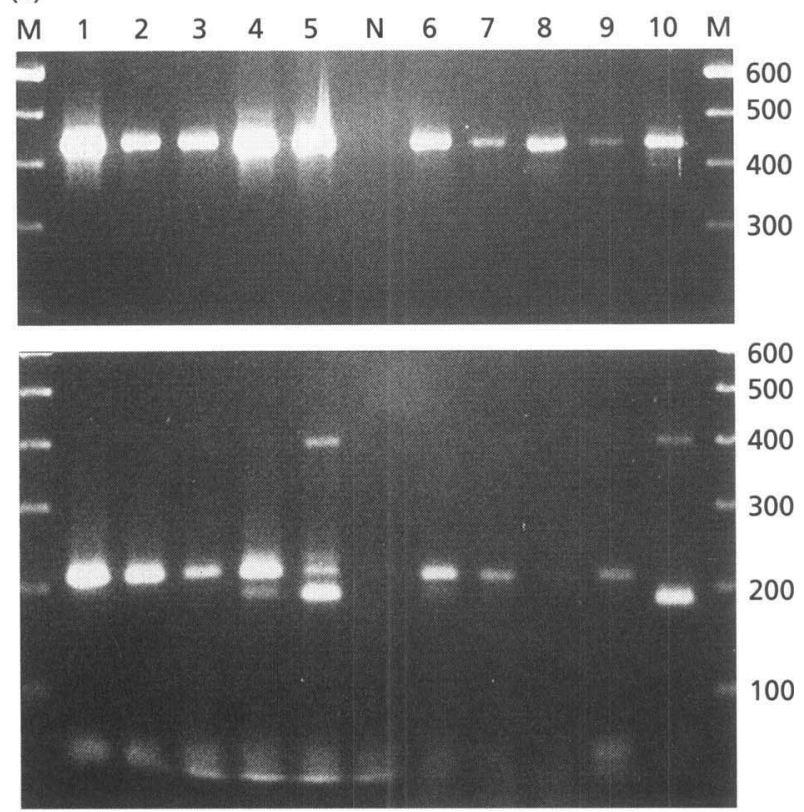

Fig. 5. Agarose gels $(2 \% \mathrm{w} / \mathrm{v})$ containing ethidium-bromide-stained PCR products obtained following amplification using either total genomic DNA as template, or CDNA which had been synthesized following reverse transcription of DNA-free total cellular RNA as template, with the ACT primer set (upper panel in each case) and the XDOM primer set (lower panel in each case). All of the amplimers shown in the upper panels hybridized with the C. albicans ACT1 gene cloned in p1002 (Mason et al., 1987). CAPLC1-homologous amplimers in the lower panels were identified by hybridization with the CAPLC1-encoding insert of pDB017 (Fig. 1). (a) The PCR products shown in the lanes (both upper and lower panels) were amplified from template DNA or CDNA from C. albicans 132A or C. dubliniensis CD48-I as follows: genomic DNA from $24 \mathrm{~h}$ yeast-phase $C$. albicans 132A (lane 1), CDNA from $7 \mathrm{~h}$ yeast-phase $C$. albicans 132A (lane 2), cDNA from $7 \mathrm{~h}$ hyphalphase $C$. albicans 132A (lane 3), CDNA from $24 \mathrm{~h}$ yeast-phase $C$. albicans 132A (lane 4), cDNA from $24 \mathrm{~h}$ hyphal-phase $C$. albicans 132A (lane 5), genomic DNA from $24 \mathrm{~h}$ yeast-phase $C$. dubliniensis CD48-I (lane 6), cDNA from $7 \mathrm{~h}$ yeast-phase $C$. dubliniensis CD48-I (lane 7), CDNA from $7 \mathrm{~h}$ hyphal-phase $C$. dubliniensis CD48-I (lane 8), CDNA from $24 \mathrm{~h}$ yeast-phase $C$. dubliniensis CD48-I (lane 9) and CDNA from $24 \mathrm{~h}$ hyphal-phase $C$. dubliniensis CD48-I (lane 10). In the lower panel the $210 \mathrm{bp}$ and $230 \mathrm{bp}$ products in lane 6 and the $400 \mathrm{bp}$ products in lanes $6-10$, in each case, did not hybridize with the CAPLC1 probe, whereas all of the other amplimers shown in the panel did. The intensity of the amplimers obtained with the ACT primers using CDNA reverse transcribed from RNA from C. dubliniensis strain CD48-I cultured in the hyphal phase were consistently weaker than the corresponding amplimers obtained from yeast-phase cultures (see upper panel, lanes 7-10). (b) The PCR products shown in the lanes (both upper and lower panels) were amplified from template DNA or cDNA from C. albicans 132A or non-C. albicans Candida isolates from yeast phase cultures ( $24 \mathrm{~h}$ for DNA and $7 \mathrm{~h}$ for RNA) as follows: genomic DNA from C. albicans 132A (lane 1), genomic DNA from C. tropicalis 709A (lane 2), genomic DNA from C. glabrata 803A (lane 3), genomic DNA from C. parapsilosis 701A (lane 4), genomic DNA from C. dubliniensis CD48-I (lane 5), CDNA from C. albicans 132A (lane 6), CDNA from C. tropicalis 709A (lane 7), cDNA from C. glabrata 803A (lane 8), CDNA from C. parapsilosis 701A (lane 9) and CDNA from C. dubliniensis CD48-I (lane 10). In the lower panel the amplimer of approximately $180 \mathrm{bp}$ in lane 4, the amplimers of approximately $210 \mathrm{bp}$ and $230 \mathrm{bp}$ in lane 5 and the $400 \mathrm{bp}$ amplimers in lanes 5 and 10 did not hybridize with the CAPLC1 probe, whereas all of the other amplimers shown in the panel did. The bands $<100 \mathrm{bp}$ in each lane are the result of primer-dimer formation. No hybridization signal was detected in lane 8 . Lanes labelled $\mathbf{N}$ are from PCR negative control experiments which lacked template DNA or CDNA. Lanes labelled M contain 100 bp ladder size reference markers (Gibco), the sizes of which are indicated.

C. albicans $132 \mathrm{~A}$ was used as a PCR template; otherwise a shorter product of $156 \mathrm{bp}$ would be expected. Following PCR amplification of cDNA made from $7 \mathrm{~h}$ and $24 \mathrm{~h}$ cultures of organisms grown in both the yeast and hyphal forms, a single amplimer of $210 \mathrm{bp}$ was obtained in each case (Fig. 5a). No amplimers were obtained in control experiments from which reverse transcriptase was omitted. This result demonstrated that the $210 \mathrm{bp}$ PCR product obtained was amplified from mRNA template reverse transcribed as cDNA and not from contaminating DNA. The $210 \mathrm{bp}$ product hybridized strongly to the cloned DNA from pDB016 (encoding $72 \%$ of the CAPLC1 gene; Fig. 1) in subsequent
Southern hybridization experiments. These data demonstrated that the CAPLC1 gene is expressed in C. albicans $132 \mathrm{~A}$, that sequences encoding the unusual stretch of 18-19 amino acids within the CAPLC1 X domain are transcribed and that the gene is expressed in both the yeast and hyphal forms of the organism. This finding rules out the possibility that the DNA sequences encoding this region constitute an intron. The possibility that the unique stretch of 18-19 amino acid residues is removed from the CAPLC1 protein by intein-mediated post-translational modification was considered unlikely because it is too short to be an intein and does not contain any of the recognized motifs thought to be involved 
(a)

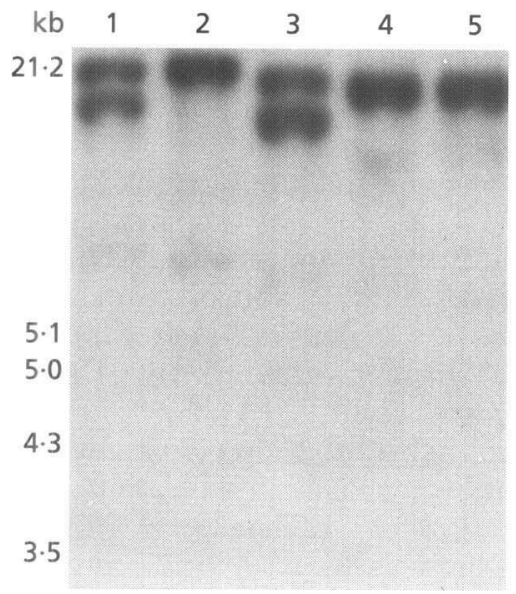

(b)

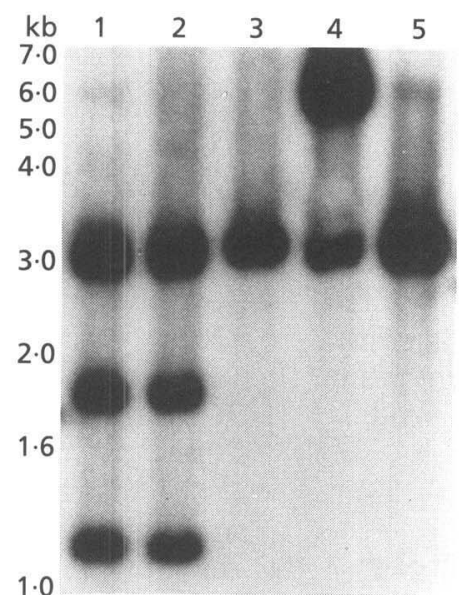

(c)

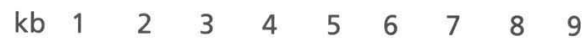

$15 \cdot 0$

$5 \cdot 0$

$4 \cdot 0$

$3 \cdot 0$

$2 \cdot 0$

Fig. 6. Southern blot analysis of CAPLC1-homologous sequences in isolates of $C$. albicans $(a, b)$ and isolates of various non-C. albicans Candida species (c) probed with the CAPLC1 DNA insert from pDB008 (Fig. 1). Genomic DNA was digested with EcoRI (a) or with Aval and Spel (b, c). DNA was from organisms as follows: (a) C. albicans $937 A 2$ (lane 1), 928 (lane 2), 935 (lane 3), 927 (lane 4) and 132A (lane 5). (b) C. albicans 927 (lane 1), 928 (lane 2), $937 A 2$ (lane 3), 935 (lane 4) and 132A (lane 5). (c) C. albicans 132A (lane 1), C. tropicalis isolates 709A and 921B (lanes 2 and 3), C. glabrata isolates 800A and 706B (lanes 4 and 5), C. parapsilosis isolates 701A and 811A (lanes 6 and 7) and C. dubliniensis isolates CD46 and CD48-I (lanes 8 and 9). Size reference markers consisting of a $1 \mathrm{~kb}$ ladder (Promega) are indicated on the left of each panel.

in splicing activity (Perler et al., 1994; F. Perler, personal communication).

To determine the size of the CAPLC1 mRNA transcript in C. albicans 132A, total RNA was isolated from the yeast and hyphal forms of the organism following $7 \mathrm{~h}$ and $20 \mathrm{~h}$ growth, in each case, and Northern hybridization experiments were performed using the CAPLC gene from pDB017 as a probe. No transcripts that hybridized with the probe were detected in each of ten separate experiments with separate preparations of RNA. In positive control experiments RNA was probed with a portion of the gene encoding elongation factor 3 (TEF3), and TEF3 mRNA signals were detected from all cultures. Since TEF3 mRNA is expressed under most conditions in yeast and hyphal forms of C. albicans (Swoboda et al., 1994), these results suggested that CAPLC1 mRNA is expressed at very low levels under the conditions tested, and not detectable by Northern analysis. That CAPLC1 expression does occur under the conditions tested was demonstrated by the RT-PCR experiments described above, although it should be noted that this technique is immensely more sensitive than Northern blotting. It is possible that expression of CAPLC1 occurs at higher levels under conditions we have not tested such as during infection in vivo.

\section{Hybridization analysis of C. albicans with CAPLC1}

To demonstrate that the cloned DNA contained in recombinant plasmids pDB001 and pDB008 was derived from $C$. albicans $132 \mathrm{~A}$, hybridization analysis was performed using the insert DNA from both plasmids separately on C. albicans $132 \mathrm{~A}$ total cellular DNA which had been digested with EcoRI only, with AvaI only, and with AvaI and SpeI. Each probe hybridized specifically to a single $20 \mathrm{~kb}$ EcoRI fragment, a $4.5 \mathrm{~kb}$ AvaI fragment, and a $3.0 \mathrm{~kb}$ AvaI-SpeI fragment, respectively (the data obtained with EcoRI-digested DNA and with AvaI- and SpeI-cleaved DNA using the pDB008 insert as a probe are shown Fig. 6a, b, lane 5). These results confirmed that the CAPLC1 DNA cloned in pDB008 is derived from C. albicans $132 \mathrm{~A}$ and is present as a single copy per genome equivalent.

EcoRI-digested genomic DNA from 26 separate $C$. albicans oral isolates was also examined by hybridization analysis using the pDB008 insert as a probe. For 14 of the isolates, the probe hybridized to a single band of approximately $20 \mathrm{~kb}$ with EcoRI-digested DNA similar to that obtained with C. albicans $132 \mathrm{~A}$, whereas 10 isolates yielded a band of approximately $15 \mathrm{~kb}$ in addition to a $20 \mathrm{~kb}$ hybridization band (Fig. 6a, lanes 1 and 3). The remaining two isolates yielded a single EcoRI hybridization band of $15 \mathrm{~kb}$ in each case (data not shown). AvaI- and SpeI-digested genomic DNA from 10 of the C. albicans oral isolates from AIDS patients included in the study yielded three hybridization profiles with the probe. Seven of the isolates yielded a single hybridization band of $3.0 \mathrm{~kb}$ similar to C. albicans $132 \mathrm{~A}$, one isolate yielded a $3.0 \mathrm{~kb}$ band and an additional $6.0 \mathrm{~kb}$ band and the remaining two isolates yielded three hybridization bands of $3.0 \mathrm{~kb}, 1.8 \mathrm{~kb}$ and $1.2 \mathrm{~kb}$, respectively (Fig. $6 \mathrm{~b}$ ). These results indicated that in the majority of the oral isolates tested the location of EcoRI, AvaI and SpeI cleavage sites flanking the CAPLC1 gene 
were similarly arranged to C. albicans $132 \mathrm{~A}$. However, in some isolates polymorphisms in the sizes of CAPLC1encoding restriction fragments affecting only one of the CAPLC1 gene homologues in each case had occurred. Similar polymorphisms have been previously reported for the C. albicans LIP1 gene family (Fu et al., 1997).

To determine if an $\mathrm{X}$ domain containing the 'unique' stretch of 18-19 amino acid residues was encoded by other C. albicans strains, the XDOM primer set used in the RT-PCR experiments was applied to target genomic DNA from the $15 \mathrm{C}$. albicans oral isolates from AIDS patients. Following PCR amplification a single product of approximately $210 \mathrm{bp}$ was observed in each case, similar to the result obtained with C. albicans 132A (data not shown). These findings demonstrated that the presence of the unique stretch of 18-19 residues was a consistent feature in C. albicans isolates.

C. albicans $132 \mathrm{~A}$ chromosomes separated by PFGE were also hybridized with the $3.0 \mathrm{~kb}$ AvaI-SpeI CAPLC1encoding cloned DNA from pDB008. The probe hybridized to a single chromosome band approximately $1.02 \mathrm{Mb}$ in size (data not shown), which corresponded to $C$. albicans chromosome no. 7 according to the numbering system described by Magee et al. (1988, 1992).

\section{Analysis of CAPLC1 homologous sequences in Candida species other than C. albicans}

EcoRI-digested and AvaI-and SpeI-digested genomic DNA from eight non-C. albicans Candida species was tested for homology to CAPLC1 by hybridization analysis with the $3.0 \mathrm{~kb} C A P L C 1$-encoding insert DNA from pDB008. Using identical high-stringency hybridization conditions (i.e. hybridization temperature of $68^{\circ} \mathrm{C}$ ) to those used with the C. albicans isolates no or very weak hybridization signals were detected with isolates of other non-C. albicans Candida species, including C. dubliniensis $(n=10)$, C. tropicalis $(n=5)$, C. glabrata $(n=11), C$. parapsilosis $(n=2)$, and one isolate each of C. kefyr, C. krusei, C. guillermondii and C. lusitaniae. However, when experiments were repeated at a lower hybridization temperature $\left(60^{\circ} \mathrm{C}\right)$, weak hybridization signals were detected with all $10 \mathrm{C}$. dubliniensis isolates tested, three C. tropicalis isolates, one C. glabrata isolate and one C. parapsilosis isolate but with none of the C. kefyr, C. krusei, C. guillermondii and C. lusitaniae isolates. Nine of the C. dubliniensis isolates tested each yielded a single EcoRI hybridization band of approximately $20 \mathrm{~kb}$ and a single Aval/SpeI hybridization band of $3.5 \mathrm{~kb}$ (Fig. $6 \mathrm{c}$ ). The remaining $C$. dubliniensis isolate, CD46, yielded a single EcoRI hybridization band of $15 \mathrm{~kb}$ and two weak Aval/SpeI hybridization bands of approximately 3.2 and $4.8 \mathrm{~kb}$, respectively (Fig. 6c). All three C. tropicalis isolates (709A, 803B and 915B), the C. glabrata isolate (803A) and the C. parapsilosis isolate $(701 \mathrm{~A})$ which hybridized with the probe yielded single EcoRI hybridization bands, in each case, of approximately $8 \mathrm{~kb}, 3 \mathrm{~kb}$ and $6 \mathrm{~kb}$, respectively and single Aval/SpeI hybridization bands, in each case, of $3.4 \mathrm{~kb}, 3.4 \mathrm{~kb}$ and $2.8 \mathrm{~kb}$, respectively (Fig. 6c). These findings suggest that the isolates which yielded weak hybridization signals contained CAPLC1homologous sequences.

To further explore the relationship between the $C$. albicans CAPLC1 gene and the homologous sequences detected in the non-C. albicans Candida species tested, the degenerate primers originally used to PCR amplify sequences encoding part of the $\mathrm{X}$ domain from genomic DNA of C. albicans 132A (Table 1) were applied to target genomic DNA from C. dubliniensis CD48-I, C. glabrata $803 \mathrm{~A}$, C. parapsilosis $701 \mathrm{~A}$ and C. tropicalis $709 \mathrm{~A}$, all of which hybridized previously with the CAPLC1 probe. Following PCR amplification, several amplimers were obtained from each target DNA sample, one of which of $130 \mathrm{bp}$ in each case hybridized with the CAPLC1 DNA of pDB008 (data not shown). Following purification, the $130 \mathrm{bp}$ amplimer from each of the three non-C. albicans isolates tested, excluding $C$. parapsilosis, was cloned in pBluescript and its nucleotide sequence determined. Repeated attempts to clone the $130 \mathrm{bp}$ product amplified from C. parapsilosis target DNA failed. For each amplimer, the sequence of 61 bases internal to primer sequences was aligned with the corresponding sequence previously amplified from $C$. albicans 132A (Fig. 7a). The sequences of the cloned amplimers from the C. dubliniensis, C. glabrata and C. tropicalis isolates showed extensive nucleotide homology with the corresponding sequence from C. albicans and with the corresponding sequences of PLC genes previously characterized from Sacch. cerevisiae and Schiz. pombe (Fig. 7a). This finding was hardly surprising as the region of DNA amplified and sequenced encoded for part of the highly conserved $\mathrm{X}$ domain region of PLC proteins which is essential for catalytic activity.

Genomic DNA from a representative isolate of each non-C. albicans Candida species which did not hybridize with the CAPLC1 probe was also used as a template for PCR amplification using the CAPHO primer set. Following PCR amplification, while several amplimers were obtained from each target DNA sample, none in each case hybridized with the CAPLC1 DNA of plasmid pDB008 (data not shown). This result confirmed that some but not all isolates of the same species possessed a CAPLC1-homologous sequence. The variability in the presence of detectable CAPLC1-homologous sequences in isolates of C. tropicalis, C. glabrata and C. parapsilosis was very surprising. The reasons for this are unknown but it could be due to loss of common sequences following genetic rearrangements or deletion events. Failure to detect CAPLC1-homologous sequences by hybridization analysis correlated with failure to amplify CAPLC1-homologous sequences using PCR. This latter finding suggests the total absence of CAPLC1-homologous sequences or that significant differences occur in the sequence composition of PLC genes in particular isolates of non-C. albicans Candida species which failed to hybridize with the CAPLC1 probe. 
(a)

c. albicans 132A (CAPLC1)

C. dubliniensis CD48-I (CDPLC1)

c. tropicalis 709A

C. glabrata $803 \mathrm{~A}$

S. cerevisiae (SCPLC)

S. pombe (SPPLC)
1749 AACTGGTCGACAAGTTGCTGGTGATTCATCAGTAGAAGGGTATATACGAACATTACAACGT AACTGGTCGACAAGTTGCTGGTGATTCATCAGTAGAAGGATATATAAGAACATTACAACGT $96.7 \%$ AACTGGTCGAAAAGTTGCTCGTGATTCATCAGTAGACGGGTATATACGAACATTACAAAGT $93.4 \%$ CACTGGCAACAAATAGGTGGGGCACCATCAGTAGAQGGGTATATACACGCATTACAGCAM 68.98 1197 ATHEGGGAACAAATTGCAGAAACTCCATCTGTGGAGGGATATATPCAAGTCCTACAACAM 59.08 1379 ACTAGGTAACCAGTTTGGTGGAGAAACTTCAATTGAAGGTATATCCGTTCCCTACAGECT 59.08

(b)

c. albicans $132 \mathrm{~A}$ (CAPLC1)

C. dubliniensis CD48-I (CDPLC1)
585 GRQVAGDSSVEGYIRTLQRGCRCVEIDIWNGDSNTTTTTVIGTKDDDDKNEYEPIVNHGRTFTKPIS GRQVAGDSSVEGYIRTLQRGCRCVEIDIWNGDSNDTGSDV------KNESEPIVNHGRTFTKPIS 80.68

Fig. 7. (a) Comparison of nucleotide sequences of CAPLC1-homologous amplimers obtained by PCR using template genomic DNA from C. albicans 132A (cloned in pDB001; Figs 1a and 2), C. dubliniensis CD48-I, C. tropicalis 709A and C. glabrata 803A with the degenerate CAPHO oligonucleotide primer set (Table 1) and the corresponding regions of the previously characterized PLC genes from Sacch. cerevisiae (SCPLC; Yoko-o et al., 1993) and Schiz. pombe (SPPLC; Fankhauser et al., 1995). Nucleotide sequences corresponding to the PCR primers are not included in the alignments. Nucleotides which differ from the $C$. albicans 132A CAPLC1 sequence are emphasized in bold. Nucleotide co-ordinates shown on the left of the figure for CAPLC1 are numbered as in Fig. 2. The nucleotide co-ordinates for the Sacch. cerevisiae and Schiz. pombe sequences are as published. Values shown on the right refer to the percentage identity of each sequence with the corresponding region from the $C$. albicans 132A CAPLC1 gene. (b) Alignment of the amino acid sequence deduced from the nucleotide sequences of cloned amplimers obtained with template genomic DNA from $C$. albicans 132A and $C$. dubliniensis CD48-I using the XDOM primer set (Table 1). These primers were specifically designed to amplify the region of DNA $(210 \mathrm{bp}$ ) which encoded the novel stretch of $18 / 19$ amino acids (residues underlined) present in CAPLC1 $X$ domain. The XDOM primers amplified a CAPLC1-homologous PCR product of 180 bp with genomic DNA from C. dubliniensis CD48-I. The nucleotide sequence of this region from C. dubliniensis only encoded for 11 amino acids in the region corresponding to the $C$. albicans novel stretch of amino acids. Asterisks indicate identical residues and dots represent similar residues. Dashes indicate gaps created to obtain alignment. Residue co-ordinates shown on the left of the figure for CAPLC1 are numbered as in Fig. 2. The percentage identity of the aligned sequences is shown on the right.

Chromosome-sized DNA molecules from C. tropicalis 709A, C. glabrata 803A, C. parapsilosis 701A and C. dubliniensis CD48-I and CD46 were separated by PFGE and were hybridized with the CAPLC1 DNA of plasmid pDB008 (data not shown). The probe hybridized to single chromosome bands of approximately $1.2 \mathrm{Mb}$, $1.1 \mathrm{Mb}$ and $1.0 \mathrm{Mb}$ in C. tropicalis 709A, C. glabrata $803 \mathrm{~A}$ and C. parapsilosis 701A, respectively. However, the probe hybridized to two chromosome bands each in the two C. dubliniensis isolates, a $1.0 \mathrm{Mb}$ and a $2 \cdot 2 \mathrm{Mb}$ band in isolate CD46, and a $1.2 \mathrm{Mb}$ and a $2 \cdot 2 \mathrm{Mb}$ band in isolate CD48-I. It is possible that the pattern observed in both C. dubliniensis isolates is a result of chromosome fragmentation, a phenomenon which has previously been observed in other C. dubliniensis karyotype profiles (Coleman et al., 1997; D. Sullivan \& D. C. Coleman, unpublished data).

Because all 10 of the C. dubliniensis isolates included in the study hybridized with CAPLC1 and because previous studies have shown that $C$. dubliniensis is the species phylogenetically most closely related to C. albicans (Sullivan et al., 1995, 1996, 1997), experiments were performed to determine whether the $C$. dubliniensis sequences homologous to CAPLC1 encoded a similar novel stretch of amino acids as detected within the $\mathrm{X}$ domain of the C. albicans CAPLC1 protein (Fig. 4). The $\mathrm{XDOM}$ primer set, which was complementary to sequences encoding this region in C. albicans $132 \mathrm{~A}$ (Table 1), was used to amplify sequences from $C$. dubliniensis CD48-I and CD46 DNA. Two amplimers, of approximately $180 \mathrm{bp}$ and $380 \mathrm{bp}$, respectively, were obtained in each case, only the smaller of which hybridized with the CAPLC1-encoding DNA from pDB008. Both amplimers from C. dubliniensis CD48-I were purified, cloned in pBluescript and their nucleotide sequences determined. The deduced amino acid sequence of the larger amplimer (359 bp) exhibited no homology with any previously characterized $P L C$ gene in the GenBank database (analysis performed in March 1997), whereas that of the smaller amplimer (179 bp) shared $80.6 \%$ overall amino acid identity $(82.1 \%$ similarity) with the corresponding C. albicans sequence (Fig. 7b). However, the C. dubliniensis sequence only encoded 11 amino acids in the region corresponding to the C. albicans 'novel' stretch of 19 residues, only six of which were identical and one similar to the corresponding C. albicans sequence (Fig. $7 \mathrm{~b}$ ).

To determine whether the CAPLC1-homologous sequences detected in non-C. albicans Candida species by hybridization and PCR analyses were expressed as mRNA, RT-PCR experiments were performed on total cellular RNA from $24 \mathrm{~h}$ broth cultures of one isolate of C. dubliniensis, and one isolate in each case of those C. tropicalis, C. glabrata and C. parapsilosis isolates which 
exhibited CAPLC1 homology. Amplimers of similar size to those obtained with C. dubliniensis CD48-I, C. tropicalis 709A, C. parapsilosis 701A genomic DNA were also obtained when cDNA made from these isolates was used as a PCR template with the XDOM primer set (Fig. 5b). These findings showed that $C$. dubliniensis, C. tropicalis and C. parapsilosis CAPLC1associated DNA was present as mRNA transcripts and was therefore expressed. mRNA was also found to be present in C. dubliniensis isolate CD48-I following growth in both the yeast and hyphal phases at both $7 \mathrm{~h}$ and 24 time intervals, in each case (Fig. 5a). However, no amplimer was detected with cDNA from C. glabrata 803A. An amplimer of the expected size ( $440 \mathrm{bp}$ ) was obtained when the same cDNA preparation from $C$. glabrata 803A cDNA was used as a PCR template with the ACT primer set (Table 1) which served as a positive control for cDNA synthesis and RT-PCR (Fig. 5b). This suggested that the C. glabrata 803A CAPLC1-associated DNA sequence was not present as an mRNA transcript and was therefore not expressed under the conditions used.

\section{Phospholipase C activity of Candida species}

All of the Candida isolates used in hybridization experiments were tested for PLC activity using $p$-NPPC following growth in YPD for $20 \mathrm{~h}$. The PLC activities in units (mg protein $)^{-1}$ in cell-free protein extracts of the isolates examined ranged as follows: $C$. dubliniensis $(n=10), 6 \cdot 0-18.2$ [mean $9.6 \pm 3.4] \times 10^{-2} ;$ C. glabrata $(n=11), 1.9-4.6$ [mean $3.1 \pm 0.8] \times 10^{-2} ;$ C. tropicalis $(n=5), 6 \cdot 3-10 \cdot 9$ [mean $8 \cdot 2 \pm 1 \cdot 7] \times 10^{-2}$; C. parapsilosis $(n=2$; the individual values for each isolate are given) 4.6 and $8.6 \times 10^{-2}$, respectively. The corresponding PLC activities for the C. albicans oral carriage isolates tested $(n=3)$ ranged from 6.5 to 12.6 [mean $8 \cdot 7 \pm 2 \cdot 8] \times 10^{-2}$ units (mg protein $)^{-1}$, whereas activities for the C. albicans oral isolates from AIDS patients with oral candidosis $(n=15)$ ranged from $5 \cdot 4$ to $15 \cdot 1$ [mean $11.5 \pm 3.9] \times 10^{-2}$ units $(\mathrm{mg} \text { protein })^{-1}$.

\section{Concluding remarks}

We have described the genetic characterization of the first PLC gene, termed CAPLC1, to be cloned from the pathogenic yeast $C$. albicans. With the development of efficient gene-targeting systems in C. albicans it is possible to use cloned DNA sequences to generate null mutants of specific genes (Fonzi \& Irwin, 1993; Gow et al., 1994) and to study non-lethal mutations (Brown et al., 1996). The precise role of the CAPLC1 gene in C. albicans is unknown; however, based on sequence homology with previously characterized PLC $\delta 1$ genes from other yeasts and from higher eukaryotes and the presence of conserved regions within the predicted CAPLC1 protein, it is likely that CAPLC1 is involved in signal transduction. The presence of CAPLC1-related sequences in several non-C. albicans Candida species also indicated that these species contain PLC genes, which very probably perform a similar function to
CAPLC1. By disrupting the CAPLC1 gene we hope to investigate the role of this PLC $\delta 1$ isoform in the yeast $C$. albicans. These studies and more detailed investigations of PLC genes in non-C. albicans Candida species are currently under way.

\section{ACKNOWLEDGEMENTS}

This work was supported in part by a grant from the Wellcome Trust (no. 047204) and by the Dublin Dental Hospital. We thank Professor Robert Kresinger, University of Virginia, Charlottesville, USA, for his advice on EF-hand domains and Dr Francine Perler, New England Biolabs, MA, USA, for her advice on protein splicing. We would also like to gratefully acknowledge the constant encouragement and support of Professor D. Shanley (Dublin Dental Hospital).

\section{REFERENCES}

Altschul, S. F., Gish, W., Miller, W., Myers, E. W. \& Lipman, D. J. (1990). Basic local alignment search tool. J Mol Biol 215, 403-410.

Bairoch, A. \& Cox, J. A. (1990). EF-hand motifs in inositol phospholipid-specific phospholipase C. FEBS Lett 269, 454-456.

Banno, Y., Yamada, T. \& Nozawa, Y. (1985). Secreted phospholipases of the dimorphic fungus, Candida albicans; separation of three enzymes and some biological properties. J Med Vet Mycol 23, 47-54.

Barrett-Bee, K., Hayes, Y., Wilson, R. G. \& Ryley, J. F. (1985). A comparison of phospholipase activity, cellular adherence and pathogenicity of yeasts. J Gen Microbiol 131, 1217-1221.

Bayer, M. H. \& Bayer, M. E. (1985). Phosphoglycerides and phospholipase $\mathrm{C}$ in membrane fractions of Escherichia coli B. $J$ Bacteriol 162, 50-54.

Berridge, M. (1993). Inositol trisphosphate and calcium signalling. Nature 361, 315-325.

Brown, A. J. P. \& Lithgow, G. J. (1987). The structure and expression of nuclear genes in Saccharomyces cerevisiae. In Gene Structure in Eukaryotic Microbes, pp. 1-26. Edited by J. R. Kinghorn. Oxford: IRL Press.

Brown, D. H., Jr, Slobodlin, I. V. \& Kumamoto, C. A. (1996). Stable transformation and regulated expression of an inducible reporter construct in Candida albicans using restriction enzyme-mediated integration. Mol Gen Genet 251, 75-80.

Cheng, H.-F., Jiang, M.-J., Chen, C.-L., Liu, S.-M., Wong, L.-P., Lomasney, J. W. \& King, K. (1995). Cloning and identification of amino acid residues of human phospholipase $\mathrm{C} \delta 1$ essential for catalysis. J Biol Chem 270, 5495-5505.

Cifuentes, M. E., Honkanen, L. \& Rebecchi, M. J. (1993). Proteolytic fragments of phosphoinositide-specific phospholipase C- $\delta_{1} . J$ Biol Chem 268, 11586-11593.

Coleman, D. C., Sullivan, D. J., Bennett, D. E., Moran, G. P., Barry, H. J. \& Shanley, D. B. (1997). Candidiasis: the emergence of a novel species, Candida dubliniensis. AIDS 11, 557-567.

Colthurst, D. R., Schauer, B. S., Hates, M. V. \& Tuite, M. F. (1992). Elongation factor 3 (EF-3) from Candida albicans shows both structural and functional similarity to EF-3 from Saccharomyces cerevisiae. Mol Microbiol 6, 1025-1033.

Costa, A. L., Costa, C., Misefari, A. \& Amato, A. (1968). On the enzymatic activity of certain fungi. VII. Phosphatidase activity on media containing sheep's blood of pathogenic strains of Candida albicans. Atti Soc Peloritana Sci Fis Mat Nat XIV, 93-101.

Drayer, A. L. \& van Haastert, P. J. M. (1992). Molecular cloning 
and expression of a phosphoinositide-specific phospholipase $\mathrm{C}$ of Dictyostelium discoideum. J Biol Chem, 267, 18387-18392.

Ellis, M. V., Carne, A. \& Katan, M. (1993). Structural requirements of phosphatidylinositol-specific phospholipase C delta 1 for enzyme activity. Eur J Biochem 213, 339-347.

Emini, E. A., Hughes, J. V., Perlow, D. S. \& Bolger, J. (1985). Induction of hepatitis A virus-neutralizing antibody by a virusspecific synthetic peptide. J Virol 55, 836-839.

Essen, L.-O., Perisic, O., Cheung, R., Katan, M. \& Williams, R. L. (1996). Crystal structure of a mammalian phosphoinositidespecific phospholipase C $\delta$. Nature 380, 595-602.

Fankhauser, H., Schweingruber, A. M., Edenharter, E. \& Schweingruber, M. E. (1995). Growth of a mutant defective in a putative phosphoinositide-specific phospholipase C of Schizosaccharomyces pombe is restored by low concentrations of phosphate and inositol. Curr Genet 28, 199-203.

Fonzi, W. A. \& Irwin, M. Y. (1993). Isogenic strain construction and gene mapping in Candida albicans. Genetics 134, 717-728.

Frischauf, A. M., Lehrach, H., Poustka, A. \& Murray, N. (1983). Lambda replacement vectors carrying polylinker sequences. J Mol Biol 170, 827-842.

Fu, Y., Ibrahim, A. S., Fonzi, W., Zhou, X., Ramos, C. F. \& Ghannoum, M. A. (1997). Cloning and characterization of a gene (LIP1) which encodes a lipase from the pathogenic yeast Candida albicans. Microbiology 143, 331-340.

Gallagher, P. J., Bennett, D. E., Henman, H. C., Russell, R. J., Flint, S. R., Shanley, D. B. \& Coleman, D. C. (1992). Reduced azole susceptibility of Candida albicans from HIV-positive patients and a derivative exhibiting colony morphology variation. J Gen Microbiol 138, 1901-1911.

Genetics Computer Group (1994). Program manual for the GCG package, version 8.0, September 1994. Madison, WI: Genetics Computer Group.

Gow, N. A. R., Robbins, P. W., Lester, J. W., Brown, A. J. P., Fonzi, W. A., Chapman, T. \& Kinsman, O. S. (1994). A hyphal-specific chitin synthase gene (CHS2) is not essential for growth, dimorphism, or virulence of Candida albicans. Proc Natl Acad Sci USA 91, 6216-6220.

Higgins, D. G. \& Sharp, P. M. (1988). Clustal: a package for performing multiple sequence alignment on a microcomputer. Gene 73, 237-244.

Hube, B., Monod, M., Schofield, D. A., Brown, A. J. P. \& Gow, N. A. R. (1994). Expression of seven members of the gene family encoding secretory aspartyl proteinases in Candida albicans. Mol Microbiol 14, 87-99.

Ibrahim, A. S., Mirbod, F. S., Filler, G. S., Banno, Y., Cole, G. T., Kitajima, Y., Edwards, J. E., Jr, Nozawa, Y. \& Ghannoum, M. A. (1995). Evidence implicating phospholipase as a virulence factor of Candida albicans. Infect Immun 63, 1993-1998.

Ibrahim, A. S., Fu, Y., Fonzi, W., Zhou, X., Mirbod, F., Nakashima, S., Nozawa, Y. \& Ghannoum, M. A. (1996). Cloning, and expression of Candida albicans extracellular phospholipase B. In Abstracts of the 34th Infectious Diseases Society of America Meeting, New Orleans, abstract 220.

Karplus, P. A. \& Schulz, G. E. (1985). Prediction of chain flexibility in proteins. Naturwissenschaften 72, 212-213.

Kurioka, S. \& Matsuda, M. (1976). Phospholipase C assay using $p$ nitrophenylphosphoryl-choline together with sorbitol and its application to studying the metal and detergent requirement of the enzyme. Anal Biochem 75, 281-289.

Kurtz, M. B., Kelly, R. \& Kirsch, D. R. (1990). Overview of Candida physiology, pathogenicity, and new anticandidial agents. In The
Genetics of Candida, pp. 1-19. Edited by D. R. Kirch, R. Kelly \& M. B. Kurtz. Boston: CRC Press.

Leonis, M. A. \& Silbert, D. F. (1996). Genomic organization of the hamster phospholipase C- $\delta_{1}$ gene: differential loss of separate alleles of the phospholipase C- $\delta_{1}$ gene in two fibroblast mutants lacking phospholipase C- $\delta_{1}$. Biochem Biophys Res Commun 224, 382-390.

Losberger, C. \& Ernst, J. F. (1989). Sequence of the Candida albicans gene encoding actin. Nucleic Acids Res 17, 9488.

Magee, B. B., Koltin, Y., Gorman, J. A. \& Magee, P. T. (1988). Assignment of cloned genes to the seven electrophoretically separated Candida albicans chromosomes. Mol Cell Biol 8, $4721-4726$.

Magee, P. T., Bowdin, L. \& Staudinger, J. (1992). Comparison of molecular typing methods for Candida albicans. J Clin Microbiol 30, 2674-2679.

Mason, M., Lasker, B. \& Riggsby, W. S. (1987). Molecular probe for identification of medically important Candida species and Torulopsis glabrata. J Clin Microbiol 23, 563-566.

Mensa-Wilmot, K. \& Englund, P. T. (1992). Glycosyl phosphatidylinositol-specific phospholipase C of Trypanosoma brucei: expression in Escherichia coli. Mol Biochem Parasitol 56, 311-322.

Milting, H., Heilmeyer, L. M., Jr \& Thieleczek, R. (1996). Cloning of a phospholipase C-delta 1 of rabbit skeletal muscle. J Muscle Res Cell Motil 17, 79-84.

Mirbod, F., Banno, Y., Ghannoum, M. A., Ibrahim, A. S., Nakashima, S., Kitajima, Y., Cole, G. T. \& Nozawa, Y. (1995). Purification and characterization of lysophospholipasetransacylase (h-LPTA) from a highly virulent strain of Candida albicans. Biochim Biophys Acta 1257, 181-188.

Mitchell, R. H. (1992). Inositol lipids in cellular signalling mechanisms. Trends Biochem Sci 17, 274-276.

Moran, G. P., Sullivan, D. J., Henman, M. C., McCreary, C. E., Harrington, B. J., Shanley, D. B. \& Coleman, D. C. (1997). Antifungal drug susceptibilities of oral Candida dubliniensis isolates from human immunodeficiency virus (HIV)-infected and nonHIV-infected subjects and generation of stable fluconazoleresistant derivatives in vitro. Antimicrob Agents Chemother 41, $617-623$.

Nakashima, S., Banno, Y., Watanabe, T., Nakamura, Y., Mizutani, T., Saki, H., Zhao, Y., Sugimoto, Y. \& Nozawa, Y. (1995). Deletion and site-directed mutagenesis of EF-hand domain of phospholipase C- $\delta 1$ : effects on its activity. Biochem Biophys Res Commun 211, 364-369.

Nishizuka, Y. (1992). Intracellular signalling by hydrolysis of phospholipids and activation of protein kinase C. Science 258, 607-614.

Perler, F. B., Davis, E. O., Dean, G. E., Gimble, F. S., Jack, W. E., Neff, N., Noren, C. J., Thorner, J. \& Belfort, M. (1994). Protein splicing elements : inteins and exteins - a definition of terms and recommended nomenclature. Nucleic Acids Res 22, 1125-1127.

Price, M. F. \& Cawson, R. A. (1977). Phospholipase activity in Candida albicans. Sabouraudia 15, 179-185.

Pugh, D. \& Cawson, R. A. (1975). The cytochemical localization of phospholipase and lysophospholipase in Candida albicans. Sabouraudia 13, 110-115.

Pugh, D. \& Cawson, R. A. (1977). The cytochemical localization of phospholipase in Candida albicans infecting the chick chorioallantoic membrane. Sabouraudia 15, 29-35.

Rhee, S. G. \& Choi, K. D. (1992). Regulation of inositol phospholipid-specific phospholipase C isozymes. J Biol Chem 267, 12393-12396. 
Rhee, S. G., Suh, P.-G., Ryu, S.-H. \& Lee, S. Y. (1989). Studies of inositol phospholipid-specific phospholipase C. Science 244, 546-550.

Sambrook, J., Fritsch, E. F. \& Maniatis, T. (1989). Molecular Cloning: a Laboratory Manual, 2nd edn. Cold Spring Harbor, NY: Cold Spring Harbor Laboratory.

Sanger, F., Nicklen, S. \& Coulson, A. R. (1977). DNA sequencing with chain-terminating inhibitors. Proc Natl Acad Sci USA 74, 5463-5467.

Southern, E. (1975). Detection of specific sequences among DNA fragments separated by gel electrophoresis. $J \mathrm{Mol}$ Biol 98, 503-517.

Suh, P.-G., Ryu, S. H., Moon, K. H., Suh, H. W. \& Rhee, S. G. (1988). Cloning and sequence of multiple forms of phospholipase C. Cell 54, 161-169.

Sullivan, D. J., Westerneng, T. J., Haynes, K. A., Bennett, D. E. \& Coleman, D. C. (1995). Candida dubliniensis sp. nov.: phenotypic and molecular characterization of a novel species associated with oral candidosis in HIV-infected individuals. Microbiology 141, 1507-1521.

Sullivan, D. J., Henman, M. C., Moran, G. P., O'Neill, L. C., Bennett, D. E., Shanley, D. B. \& Coleman, D. C. (1996). Molecular genetic approaches to identification, epidemiology and taxonomy of non-albicans Candida species. J Med Microbiol 44, 399-408.

Sullivan, D., Haynes, K., Bille, J., Boerlin, P., Rodero, L., Lloyd, S., Henman, M. \& Coleman, D. (1997). Widespread geographic distribution of oral Candida dubliniensis strains in human immunodeficiency virus-infected individuals. J Clin Microbiol 35, 960-964.
Swoboda, R. K., Bertram, G., Colthurst, D. R., Tuite, M. F., Gow, N. A. R., Gooday, G. W. \& Brown, A. J. P. (1994). Regulation of the gene encoding translation factor 3 during growth and morphogenesis in Candida albicans. Microbiology 140, 2611-2616.

Takahashi, M., Banno, Y. \& Nozawa, Y. (1991). Secreted Candida albicans phospholipases: purification and characterization of two forms of lysophospholipase-transacylase. J Med Vet Mycol 29, 193-204.

Vazquez, J. A., Beckley, A., Sobel, J. D. \& Zervos, M. J. (1991). Comparison of restriction enzyme analysis and pulsed-field gradient gel electrophoresis as typing systems for Candida albicans. J Clin Microbiol 29, 962-967.

Wolf, H., Modrow, S., Motz, M., Jameson, B., Hermann, G. \& Fortsch, B. (1987). An integrated family of amino acid sequence analysis programs. Comput Appl Biosci 4, 187-191.

Yagisawa, H., Hirata, M., Kanematsu, T., Watanabe, Y., Ozaki, S., Sakuma, K., Tanaka, H., Yabuta, N., Kamata, H., Hirata, H. \& Nojima, H. (1994). Expression and characterization of an inositol 1,4,5-triphosphate binding domain of phosphatidylinositolspecific phospholipase C-delta 1. J Biol Chem 269, 20179-20188.

Yoko-o, T., Matsui, Y., Yagisawa, H., Nojima, H., Uno, I. \& Toh-e, A. (1993). The putative phosphoinositide-specific phospholipase C gene, PLC1, of the yeast Saccharomyces cerevisiae is important for cell growth. Proc Natl Acad Sci USA 90, 1804-1808.

Received 3 July 1997; revised 22 September 1997; accepted 30 September 1997. 